\title{
Estuddos experimentais sôbre a origem do milho
}

\author{
F. G. Brieger
}

Escola Superior de Agricultura

"Luiz de Queiroz", Universidade

de São Paulo

\section{INDICE}

1 -Introduçāo

$22 f$

A - As hipóteses antigas 226

B - A hipótese de Mangelsdorf and Reeves 227

C - Resumo

232

2-A reconstruçāo do milho selvagem

A - O problema

B - Os estudos genéticos 233

C - Explicação genética de reversão atavistica

3-Reconstrução da domesticação

A - O primeiro passo de domesticação

B - A hipótese da hibri. dação e o "inbreeding"

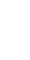
243

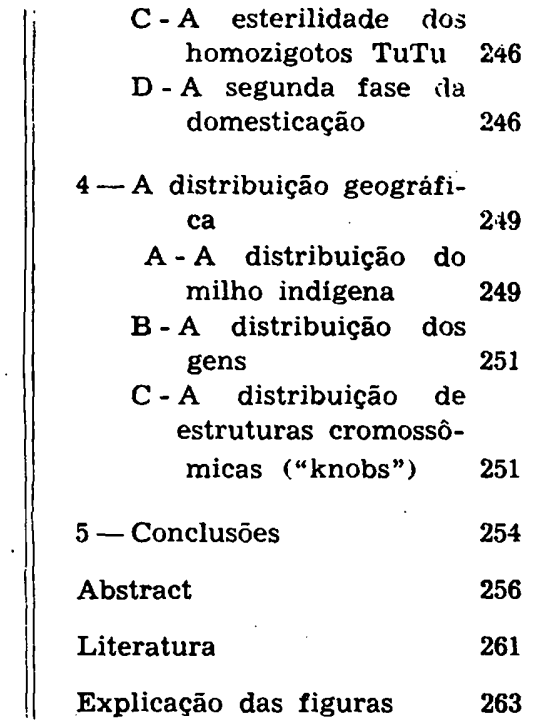




\section{1 - INTRODUC̣ÃO}

\section{A) As hipóteses antigas}

O milho ocupa ainda hoje entre as plantas cultivadas uma posição muito excepcional, pelo fato de que não se conhecem espécies selvagens que possam ser consideradas como os tipos ancestrais ou, no minimo, como uma aproximação ao "milho selvagem". Não houve uma evolução do milho nos últimos séculos que nos permitisse tirar conclusões sôbre o que aconteceu no inicio da sua domesticação. As variedades que foram encontradas em cultivo por ocasião da descoberta das Américas foram $\mathrm{km}$ grande parte idênticas às variedades ainda hoje cultivadas, e não há restos "fósseis" pròpriamente ditos de milho, inas apenas espigas ou reproduções encontradas nos túmulos de tempos antes de Cristo, às quais correspondem exaiamente as variedades que os indios ainda hoje cultivam, como demonstrado na fig. 1. (COLLINS 1923, ANDERSON AND BLANCHARD, 1942).

Assim somos forçados tentar solucionar o problema da crigem do milho por processos indiretos, e também não devemos ficar admirados que uma questão tão interessante e que se refere a um cereal de tal valor mundial ainda não tenha encontrado uma soluçâo satisfatória e final.

A maioria dos trabalhos que se ocupam com o problema é muito empírica, aproveitando-se de tóda sorte de observações, mais ou menos acidentais. Também as duas hipóteses básicas não são produtos de experimentos dirigidos. Obtendo uma parte de uma espiga de milho Tunicata do Brasil, ST. HILAIRE (1829) formula a sua hipótese de que êste tipo fôsse a melhor aproximação até então conhecida ao tipo selvagem. De outro lado, ASCHERSON (1875), depois da descuberta da Euchlaena mexicana, concluiu que talvez esta espécie fôsse 0 ancestral do milho ou no mínimo uma forma próxima a êle. Estudando o ótimo resumo da literatura sóbre o assunto na publicação de MANGELSDORF e REEVES (1939), nuta-se que os autores, posteriores aos dois citados, frequentemente propuzeram novas hipóteses, sem explicar porque os conceitos anteriores tinham que ser modificados e porque as novas conclusões tinham mais probabilidade de serem certas. Ultimamente os estados sôbre o assunto tomaram novo impulso.

MANGELSDORF and REEVES (1939) compararam os descendentes do cruzamento entre variedades de Zea Mays e Tripsacum dactyloides de um lado, de Zea e Euchlaena mexicana de outro e tiraram as suas conclusões dêste material. 
As minhas experiências foram iniciadas em 1937 , pouco depois da minha chegada ao Brasil, com o intúito de aproveitar o material sul-americano para, ou achar ainda formas remanescentes do tipo selvagem, ou recompó-las por cruzamentos. Um primeiro resumo dos resultados foi publicado em 1943. Os experimentos já estavam bem encaminhados quando MANGELSDORF e REEVES (1939) publicaram o seu trabalho detalhado. Apesar de várias divergencias que existem entre as nossas opinibes, verifiquel que havia um paralelismo muito pronunciado com relaçăo as outras conclusões e planos de trabalho em geral. Tendo assim perdido a prioridade da publicacăo em vários pontos, resolvi retardar a minha publicaçăo detalhada e continuar os estudos experimentais.

MANGELSDORF e REEVES discutem apenas a possibilidade de se produzir um milho selvagem sintético ("Posslbillty of Producing a Syntetic "Wild Corn", pg. 241). A descriçăo de uma tal forma experimentalmente reconstruida é o principal objeto deste trabalho.

Os meus estudos se extenderam em várias direções. Nesta publicação, porém, trataremos sòmente dos resultados que são ligados diretamente com o problema da origem do milho. Detalhes experimentais serăo relatados em tres outras publicações, sôbre a distribuiçăo e análise genética do milho indigena do centro da América do Sul (BRIEGER e CUTLER) e sôbre as relaçðes deste milho com as formas de Euchlaena mexicana (BRIEGER e ADDISON) e finalmente sôbre o estado detalhado de milho Tunicata Paulista (BRIEGER). Para não sobrecarregar o manuscrito com discussóes gerais, reuni numa publicação especial, consideraçб̋es sôbre o mecanismo da evoluḉo (BRIEGER, 1945).

\section{B) A hipotese de Mangelsdorf e Reeves}

A hipótese de MANGELSDORF e REEVES pode ser dividida em duas partes: uma que se ocupa com as relaçóes entre Zea Mays e Euchlaena mexicana e assirn tenta regeitar a teoria de ASCHERSON, enquanto que a outra parte é dedicada à explicação da origem do milho, oferecendo uma forma modernizadí da teoria de ST. HILAIRE.

Com referencia ao primeiro ponto, os resultados dos seus estudus induziram os autores a inverter a relação, considerando não mais Euchlaena como forma ancestral, mas ao contrário, como descendente do milho, depois de um cruzamento com uma espécie de Tripsacum. Posteriormente éles frisaram a hi- 
pótese mais decisivamente (REEVES and MANGELSDORF, 1942), incluindo agora teosinte no gênero Zea e considerandoo apenas como uma forma de milho, na qual algumas regióes de cromossómios foram substituidas por regióes correspondentes de alguma espécie de Tripsacum. As provas experimentais, porém, săo tódas indiretas, faltando a demonstração definitiva: a obtenção de uma forma semelhante a Euchlaena de um cruzamento Zea x Tripsacum. Em alguns pontos o julgamento dos autores me parece até por demais subjetivo.

Os resultados da análise genética do cruzamento Zea $x$ Euchlaena não apoiam de modo claro a opiniăo de MANGELSDORF and REEVES. Os autores que analisaram a segregação dos híbridos Zea $x$ Euchlaena, chegaram a opinióes bastante divergentes. COLLINS and KEMPTON (1918) chegaram à conclusão que a segregaçăo em F2 é bastante complicada, não podendo encontrar-se qualquer caso de uma segregação mendeliana definitivamente monofatorial. LANGHAM (1940), de cutro lado, achou que se trata de poucas diferenças monofatoriais. MANGELSDORF and REEVES (1939), nas análises do "backcross" (Zea x Euchlaena) x Zea, concluiram que muitas das diferenças especificas podem ser atribuidas a poucas diierenças entre regioes cromosómicas, duas das quais localizadas no cromosómio IV, que contém também o fator tunicata. As nossas observações (BRIEGER e ADIISON), em F2, F3 e "backcrosses", estão de acôrdo com as conclusões de COLLINS and KEMPTON. As diferenças das duas espécies não dão segregações simples. Além disso, muitas combinações de gens não podem ser encontradas em consequência de uma eliminação forte, tanto gônica como zigótica, nos híbridos.

A situação é diferente se estudarmos o comportamento dos gens mutados ("mutant gens") de milho que desde há muito tempo são objeto de estudos genéticos. ção clara e bem analisada em cruzamentos entre linhagens de milho, e o mesmo foi constatado nos cruzamentos com Euchlaena (EMERSON 19), (BEADLE and EMERSON, 1932, EMERSON and BEADLE, 1932, BEADLE, 1932a, AMASSON 1936, MANGELSDORF and REEVES, 1939). Daf pode-se concluir que os cromosónios destas duas espécies são em grande parte homólogos, contendo apenas aleles diferentes.

A citologia comparativa de milho e teosinte foi estudada por vários autores. De acôrdo com KEMPTON and POPENOE (1937) e LONGLEY (1937) existem três tipos de Euchlaena: Teosinte do Sul de Guatemala, do Norte do mesmo pais e do México. Nos hibridos com milho LONGLEY (1942), BEADLE 
(1932b) e O. MARA (1942) acharam pareamento normal quando foram usadas as formas de Euchlaena do Norte de Guatemala e do México, mas nos híbridos com Euchlaena do Sul de Guatemala (inclusive o chamado Teosinte da Flórida) univaientes foram encontrados com bastante frequência. interessante notar que estas mesmas irregularidades foram observadas no cruzamento entre Euchlaena do Norte e do Sul de Guatemala. LONGLEY (1937a) dá uma descriçáo detalhada da estrutura dos cromosómios de milho e das diferentes linhagens de Euchlaena.

A hipótese da origem hibrida de teosinte encontra mais uma dificuldade de natureza citológica. Todas as espécies de Tripsacum, que hoje são encontradas na América Central, são auto-tetraploides com $2 \mathrm{n}=4 \times 18=72$ cromosômios (MANGELSDORF and REEVES, 1939). Os híbridos destes auto-tetraplóides com Zea dão, de acôrdo com os mesmos autores, 18 bivalentes, formados pelos cromosômios de Tripsacum, ficando os dez cromosómios de milho univalentes. Estes híbridos foram estéreis nos estudos mencionados, mas se houvesse tido, em alguma época, híbridos um pouco férteis, éles dariam descendentes, ou por auto-fecundação ou por "backcrosses" para Tripsacum, que seriam individuos diplóides com alguns cromosómios de milho. Na medida da eliminação dos univalentes de milho, aumentaria a fertilidade. "Backcrosses" para mitho deveriam ao contrário, ser mais estéreis, pois agora, além de numerosos cromosómios do milho, todos os 18 cromosómios de Tripsacum se tornariam univalentes. Assim, deve-se esperar uma maior frequência de formas de Tripsacum com alguns caracteres de milho, do que de formas de milho com alguns caracteres de Tripsacum. Porém os autores não fazem referência alguma aos primeiros.

A situaçăo teria sido diferente se formas diplóides de Tripsacum entrassem no cruzamento. Porém, até hoje tais formas são desconhecidas na América Central, e năo se sabe na.da ainda sóbre a fllogenia das espécies déste gênero. Por enquanto se conhecem formas diplóides de $\mathbf{T}$. dactyloides da América do Norte (LONGLEY 1937, MANGELSDORF and REEVES 1939) e de T. australe da América do Sul (GRANER e ADDISON 1945).

Reunindo tôdas as observações até hoje feitas pelos vários autores, náo pode haver dúvida alguma de que a homolcgia cito-genética entre milho e teosinte é extremamente grar:de, sem que possamos concluir que uma espécie seja descendente da outra, ou se ambas as espécies são simplesmente des- 
cendentes de uma só espécie bastante remota, e que hoje não mais existe, tendo-se evoluidas depois separadamente uma da outra. A análise genética năo oferece uma base segura, não sòmente da nova hipotese de MANGELSDORF and REEVES, como também da antiga hipótese de ASCHERSON.

A segunda parte da hipótese de MANGELSDORF and REEVES se refere à origem do milho sem a interferencia de Euchlaena. Os autores juntam vários argumentos que apontam na direçăo da antiga hipótese de ST. HILAIRE, todos de natureza indireta, mas que em conjunto ficam convincentes.

As várias objeções levantadas, especialmente na época pré-mendeliana, contra a hipótese original de ST. HILAIRE, têm hoje pouco interêsse, como a aparente inconstancia do milho tunicata. De fato, até hoje ninguem foi capaz de estabelecer uma linha pura de tunicata, apesar de que os números na segregaçáo das plantas Tutu quando auto-fecundadas demonstram claramente que as plantas homozigotas TuTu são viáveis e dáo plantas fortes, que năo se distinguem claramente das heterozigotas. A maioria das heterozigotas sáo fértels, po-rém até agora as homozigotas sempre foram estéreis. A inconstancia das plantas tunicata assim é perfeitamente explicada; mas o outro lado do problema me parece muito mais importante: a esterilidade das formas homozigotas. Deve-se es"ranhar que a suposta forma "selvagem" fósse absolutamente estéril. Os dados até hoje obtidos não permitem decidir se esta esterilidade é devida à ação unicamente do gen $\mathbf{T u}$, ou se a forma homozigota TuTu contém outros gens da natureza de modificadores que provocam a falta de fertilidade. Iniciel experimentos para esclarecer definitivamente êste ponto e para estudar a base histológica da esterilidade.

Um outro ponto escapou até hoje à atenção de todos os autores, apesar de sua importáncia do ponto de vista da teoria moderna de evolução. necessário explicar como um gen, especialmente um gen com efeito tão pronunciadamente dominante, podia ter sido conservado, provàvelmente durante milhares de anos, quando êle não tem nenhuma utllidade que pudesse explicar uma seleçáo pelos índios a seu favor e quando a forma homozigota era estéril. A explicaçăo fol recentemente encontrada por CUTLER (ainda năo publicado), que observou que os indios da Bolivia acharam uma utilidade do milho Tunicata para fins da medicina mística. Os grăos cobertos de glumas estão sendo ainda hoje usados contra os maus espiritos, evidentemente desde tempos prehistóricos. A descoberta de CUTLER explica perfeitamente a conservação do gen Tu desde longo tempo. 
A hipótese antiga de ST. HILAIRE reapareceu numa forma modificada, de acórdo com os novos conhecimentos genélicos, e MANGELSDORF and REEVES opinam que o gen Tu, 11a forma homozigota e nas plantas antigas e selvagens causa, c.m combinação com gens modificadores, o aparecimento na flecha de flores hermafroditas ou fêmeas.

Como já relatado em outro trabalho (BRIEGER 1943; 1945), conseguí obter por seleção em.milho tunicata paulista formas muito mais extremas do que aquelas obtidas pelos dois autores citados. Mas tódas elas não satisfaziam a nossa esper rança e năo podiam ser consideradas como uma reconstruçăo da forma selvagem e primitiva do milho, pois náo resolvem o problema fundamental da origem da espiga. A hipótese de MANGELSDORF and REEVES não explica a origem da espiga do milho, pois tódas as plantas de milho Tunicata até hoje investigadas, como tamberm tódas as plantas de milho da consțituiçăo tutu, têm uma espiga que é a resultante do processo de seleção e domesticação.

Nas figs.2 e 3 reproduzimos fotografias de plantas inteiras e flechas com um número muito elevado de flores fêmeas, obtidas em nossos experimentos de seleçăo com heterozigotos Tutu. Em primeiro lugar é evidente que à transformação muito extrema náo depende da homozigotia do gen Tu. Em segundo lugar năo podemos considerar a transformação das flechas $\mathrm{em}$ inflorescencias hermafroditas como uma completa reversূ̃o para a forma selvagem.

As fotografias das flechas transformadas (Figs. 3, B e C) demonstram que elas mantêm a ramificaçáo típica da flecha; temos, acima da última folha, uma inflorescencia ramificada com um eixo central ("central spike") que é transformado em uma espiga com ráquis muito flexivel (Fig. 3, seta 2 e 3) e na qual encontramos na base muitos galhos laterais com 4 fileiras de espiguetas apenas. Esta estrutura de ramificação é exatamente a mesma que nós encontramos em duas linhagens de milho sul-americano, isto é, um tipo boliviano, recebido do $\mathrm{Dr}$. Cardenas (Fig. 11, A e B) e outro uma forma do millho Cateto, e encontrado na Fazenda Sta. Izabel, perto de Piracicaba (Fig. $11, \mathrm{C})$ e cedida a nós pelo $\mathrm{Sr}$. Lino Morganti. Aquí também temos a espiga central com muitas fileiras e as ramificações na base com menos, geralmente quatro fileiras, tódas elas incluidas no mesmo envollucro de palhas.

Assim, como já explicado anteriormente (BRIEGER, 1943) as plantas Tu com as flechas transformadas não nos dăo uma explicaçăo da origem do órgão principal do milho, a espiga, 
pois elas têm simplesmente duas espigas, uma na posiçăo normal lateral (seta 1 na Fig. 3) e outra terminal (setas 2 e 3 na Fig. 3).

Recentemente MANGELSDORF and CAMERON (1942) e REEVES (1944, pg. 141) apresentam as suas conclusões numa forma mais geral e que pouco aifere da antiga hipótese de ST. HILAIRE: "that cultivated maize originated from a wild form of pod corn which has once, and perhaps still is, indigenous to the lowlands of South-America". (MANGELSDORF and CAMERON, pg. 217).

\section{C - Resumo}

Podemos formular a situaçăo como ela se apresenta depois do estudo da literatura sôbre a origem do milho. Há argumentos fortes em favor da hipótese de ST. HILAIRE de que o milho tunicata é a forma mais próxima ao milho selvagem que hoje ainda existe. Mas esta hipótese tem que ser posta mais de acôrdo com os conceitos modernos da genética e da botánica; e sòmente depois disso será possivel decidir se podemos ou não acei:á-la.

Chegamos à conclusão que os fatos genéticos e citológicos năo provam de modo convincente nem a teoria de ASCHERson que milho é um descendente de Euchlaena, nem a hipótese de MANGELSDORF e REEVES, que Euchlaena é um derivado de milho, com apenas alguns segmentos dos cromosomios substituidos por regizes correspondentes de Tripsacum. Como já demonstrei (1943), os caraterísticos de Euchlaena indicam uma origem independente de ambas as espécies.

Como hipótese provisória ("working hyyothesis") sôbre a origem do milho podemos aceitar que o gen Tu é um gen remanescente selvagem ("wild relic gen"). Mas não podemos esperar que a ação fenotipica do gen $\mathbf{T u}$ no milho selvagem tivesse sido a mesma que aquela encontrada hoje no milho cultivado. Sabemos (BRIEGER 1945) que as nsudanças do conjunto de modificadores (modifier shift) podem alterar profundamente a ação de gens principais ou determinadores, e não pode haver dúvida de que na passagem do tipo selvagem para a forma doméstica houvesse profundas alteraçóes em muitos gens.

Também seria necessário decidir se todas estas alterações dependiam apenas da ocorrência de mutações e sua seleção, ou se durante o processo da domesticação cruzamentos também foram empregados. 
O caminho experimental que deve ser seguido hoje consiste numa tentativa de reconstruir, por métodos genéticos, tanto quanto possivel, a forma primitiva e selvagem.

\section{2) A RECONSTRUÇÃO DO MILHO SELVAGEM}

\section{A - 0 problema}

Antes de tentar a reconstrução, por métodos genéticos, da forma selvagem e primitiva, parece indicado explicar em primeiro lygar o que nós consideramos para o milho como um conjunto de caracteres primitivos. Todos os característicos, deixando naturalmente de lado anormalidades do milho comum, são encontrados nas outras gramíneas, exceto apenas a sspiga. Será então necessário em primeiro lugar alterar a forna da espiga e reduzíla a uma forma mais primitiva, que deve te: no mínimo os seguintes caraterísticos essenciais : número de fileiras reduzido a duas ou quatro no máximo, grãos individualmente protegidos e presença de um mecanismo para a separação dos grãos quando maduros.

Deixamos por enquanto de lado outros caraterísticos botânicos que me parecem relativamente menos importantes, como a esterilidade de uma flor em cada espigueta fêmea, a grossura e rigidez da ráchis, a diferença entre inflorescências iaterais e terminais.

Por razões botânicas temos que admitir no mínimo duas possibilidades de satisfazer cada uma das exigências mínimas:

número de filleiras: proteção de sementes: separação dos grãos:

$$
2 \times 1=2
$$$$
\text { pela ráchis }
$$
ráchis quebradiça
$2 \times 2=4$ pelas glumas grãos separando-se da ráchis

É interessante notar que a situação mencionada em primeiro lugar e em relação a todos os caraterísticos é encontrada em Tripsacum e seu parente Euchlaena. Aquí os grãos são arranjados em apenas duas fileiras opostas, apesar de que cada fileira é de fato ainda dupla, contendo sempre uma esfigueta fértil e uma reduzida e estéril a qual raramente se desenvolve. Os grãos são essencialmente protegidos por crescimentos laterais e bractóides da ráchis e que chamamos de "tapas". (Fig. 4, A e B, e Fig. 13). Uma exceção encontramos is vezes em uma forma de Tripsacum australe (Fig. 13, B e D), 
onde as tapas são relativamente pequenas e as glumas muito compridas. Finalmente, quando maduras, as espigas se desartículam por completo, ficando cada internodio da ráchis com um grăo separado dos demais.

Não pode haver dúvida de que as formas mais primitivas de Maydeae deviam ter tido duas fileiras duplas, representando Tripsacum e Euchlaena uma redução filogenética neste sentido. também bem possivel, a julgar pelas anormalidades que às vezes săo encontradas em milho e Tripsacum que originalmente as fileiras de cada lado da espiga eram diferenciadas, com uma fila de espiguetas sésseis e fêmeas ou hermafroditas e outra com espiguetas pedunculadas e machos ou também hermafroditas. Uma tal situação é o normal nos gêneros de Manisurus e Rotboelia.

Com referência à segunda série de caracteres, encontramos certos indícios entre as formas de milho.

LANGHAM (1940) relatou um caso de espigas com $2 \times 2$ $=4$ tileiras. Em meu material de milho precoce e doce apareceram dois tipos: um com espigas que tinham fileiras numerosas na base, e apenas quatro fileiras na ponta, e um outro tipo com espigas que eram completamente formadas por quatro Iileiras. A genética e a origem como mutação ou recombinação dêste caráter não é ainda bastante clara em ambos os casos. Mas a morfologia das espigas com 4 flleiras é bastante interessante, pois aparece uma assimetria entre a face ventral e dorsal.

A proteção dos grãos pelas glumas é o principal carateristico du milho Tunicata. Além disso encontramos não raramente em milho indígena do Centro da América do Sul, grãos meio cobertos, especialmente em "Pipoca Pontuda Paulista".

Quanto à quebradicidade, notamos muitas vezes, debulhando milho brasileiro, que êle tem um tecido preto na regiăo onde os grăos eram fixados à ráchis. Este tecido talvez represente um residuo de uma antiga camada de separaçăo. Porém, nunca achamos um milho "quebradiço". Contrário à opinião de MANGELSDORF and REEVES (1939) verificamos que o sabugo de milho tunicata é extremamente duro e os grăos em geral difícels de debulhar. Também nas formas deste milho com numerosos grăos na flecha, não podemos considerar a ráchis ou as ramificações da mesma como realmente quebradiças, pois elas quebram em qualquer lugar e apenas quando bastante sécas.

Assim, era evidente, quando iniciei os trabalhos experimentais, que não existia ainda uma forma de milho que satis- 
fizesse tôdas as nossas exigências com respeito aos caracteres principais do milho selvagem, mas que isoladamente em diferentes linhagens encontramos elementos estruturais que podiam ser considerados como remanescentes do tipo selvagem.

\section{B - Os estudos genéticos}

Em primeiro lugar tentei solucionar o problema pelo esiudo do milho indigena do Brasil. As análises genéticas de milho cultivado pelos indios demonstraram que neles se encontram tipos com alguns carateristicos primitivos, porém nenhuma linhagem tem um conjunto completo de caracteres priinitivos (BRIEGER, 1943, BRIEGER e CUTLER, 1945). Voltaremos mais tarde a esta questão dos milhos indigenas brasileiros.

Mencionamos na introdução que parece bem provável que ú gen $\mathbf{T u}$ fósse um gen remanescente, com a restriçăo que a sua açáo fenotípica atual deve ser diferente, em várias direções, da ação original. Era então necessário estudar experimentalmente até que ponto uma alteração do fenótipo podia ser obtida pela seleção dos modificadores. O resultado dos meus estudos foi bastante surpreendente (BRIEGER, 1943, 1945).

Demonstrei que a açăo do gen $\mathbf{T u}$ é bastante diferente em plantas de milho e nos hibridos da primeira geração entre milho e teosinte. Sem entrar em detalhes, basta comparar as fotografias das espigas de híbridos Tutu (Figs. 7 e 8) e tutu (Figs. 5 e 6), e lembrar que nas primeiras a ráchis é muito quebradiça e nos outros extremamente rígida, e que os hibridos Tutu têm em geral mais fileiras duplas, muitas vezes compostas de espiguetas fêmeas e machos, do que os hibridos interespecificos, porém homozigotos para o gen tu.

Mas, se os híbridos da primeira geração, apenas heterozigotos para os modificadores de Euchlaena e Zea, já mostraram efeitos novos do gen Tunicata, maior diversidade poderá ser esperada quando nós conseguirmos selecionar combinaçóes homozigotas de modificadores. Por isso continuei a seleçăo, tanto em F2 como em F3 do cruzamento, como em repetidos "backcrosses para Euchlaena, sendo estes últimos provàvelmente mais importantes para a obtenção mais rápida de uma homozigotia dos modificadores.

Vamos dar agora a descrição de três tipos, sucessivamente obtidos em nossas experiências de seleção.

1.0) As espigas das plantas F1 (Milho $T u \times$ Euchlaena tu) já descritas anteriormente (1943) săo um pouco variáveis em 
detalhes. Muito comum é o tipo ilustrado na Fig. 7, A, com 2 x 2 fileiras, sendo em cada lado uma fileira com espiguetas sésseis e fêmeas e outra com espiguetas pecioladas e machos. Na face dorsal não há sinal de "tapas", que são desenvolvidas francamente na forma de pequenas brácteas na face ventral. As bases de espiguetas no lado oposto da ráchis são colocadas geralmente em alturas diferentes. talhes são bem visiveis na Flg. 7. Como já foi explicado, isto é sòmente um dos fenótipos encontrados em F1, além de outros com $2 \times 2=4$ fileiras com espiguetas fémeas ou com $2 \times 3=6$ fileiras e raramente $2 \times 4=8$ fileiras (Figs. 7 e 8 ).

A estrutura das espigas maduras é complicada pela alta frequência de grãos estéreis e mal desenvolvidos, sendo o desenvolvimento forte das glumas sempre evidente. As tapas, ainda visiveis na face ventral durante o florescimento, não crescem mais e pràticamente estão ausentes em espigas maduras. O principal caraterístico é a quebradicidade da ráchis em todos nós, nos quais se encontravam uma ou mais espiguetas com grăos bem desenvolvidos.

2.0) O segundo tipo foi encontrado em vários indivíduos do primeiro "backcross" para Euchlaena e diferiu da forma 1 acima descrita em detalhes, sem conter alguma cousa realmente divergente e nova. A variação fenotípica era bem mais reduzida. A presença de apenas duas fileiras em cada lado da ráchis era generalizada, a quebradicidade da ráchis bem acentuada, combinada com um comprimento considerável dos internódios. Isto em conjunto deu um aspecto bem carateristico (Fig. 9).

O mesmo tipo também foi encontrado, porém raramente, nas famflias de F2. Evidentemente trata-se de um genótipo que contém menos fatores de milho do que de Euchlaena, êstes ultimos ainda em parte na forma homozigota.

3.0) No segundo backross para Euchlaena, apareceram novos tipos que iam além de tudo até hoje conhecido (Fig. 10). Trata-se de plantas Tutu com duas séries de fileiras duplas. Em cada série temos uma espigueta fêmea séssil e outra pedunculada. A diferença essencial encoriramos na forma da ráchis, que é mais fina, achatada e ligeiramente "zig-zag", porém reiativamente firme com camadas de separaçăo na base do pedúnculo de cada espigueta.

Déste modo temos agora obtido um tipo de espiga muito comum nas Gramineas selvagens.

O tipo 1 e 2 podem ainda ser considerados como uma.combinação dos caraterísticos de Euchlaena e do milho cultivado, 
porém no tipo 3 temos no mínimo uma importante inovação: a flexibilidade da ráchis com as camadas de separação na base dos grãos. Este novo tipo preenche todos os requisitos que nós formulamos com respeito à espiga do milho ancestral e de forma tóda especial.

Agora restam apenas três outros caraterísticos do milho cultivado, a transformação dos quais também talvez seria necessária para terminar a reversão ao tipo selvagem.

a) Mencionaremos em primeiro lugar o desenvolvimento de palhas, isto é, de uma série de folhas, muito juntas e que são reduzidas na sua base, a bainha. Tanto a forma 3 como Euchlaena têm estas folhas. Porém, êstes órgãos protetores não são multo fechados, de modo que os grãos maduros caem fàcilmente. Elas são muito necessárias como órgãos protetores para as espigas na época do florescimento, até o chamado estado leitoso, pois somente depois dêste as glumas e outros órgãos protetores tornam-se duros.

b) Entre as carateristicas comuns para teosinte e milho, devemos mencionar a diferença entre as inflorescências laterais, que são total ou parcialmente fêmeas, e as inflorescências terminais, que são exclusivamente machos. difícil decidir se esta separação dos sexos já era um caraterístico do milho selvagem.

Podemos registrar que o gen $\mathbf{T u}$ tem um efeito forte na direçán de aproximar a estrutura da espiga e da flecha.

Nas ramificaçóes da flecha se encontram 4 fileiras de espiguetas, duas sésseis e duas pedunculadas, arranjadas em forma assimétrica, de modo que visto de cima (face ventral), as duas fileiras sésseis ficam no centro; escondendo a ráchis e as pedunculadas no lado. Tanto nas plantas da F1 (Tunicata milho $x$ teosinte) como nas F2 e F3 aparecem com frequência espigas com 4 -flleiras e o mesmo tipo de arranjamento.

O mesmo gen $\mathrm{Tu}$, combinado com modificadores de milho apenas, pode causar uma outra aproximação. Já mencionamos acima que obtive por seleção flechas com muitas barbas. Nestas é muito comum achar-se um arranjamento nas ramifica(̣̃es, idêntico ao descrito acima: quatro fileiras, das quais as duas centrais são sésseis e fêmeas e as duas externas machos e pedunculadas. De outro lado, a parte central da flecha ("central spike") se aproxima muito a uma espiga normal com ráchis flexivel.

As folhas imediatamente abaixo da flecha mostram sinais claros de uma transformação em palhas.

Este efeito do gen Tu sóbre a flecha, observado em milho 
puro, é completamente recessivo hipostático nos cruzamentos com Euchlaena de Guatemala e quase recessivo quando usam os Chalco-teosinte do México, de modo que náo poderemos esperar o seu reaparecimento nos backcrosses para esta espécie. Nas gerações F2 êle já reapareceu, em combinação com alguns caraterísticos de Euchlaena.

Os efeitos do gen Tu sobre a espiga observada nos hibridos e backcrosses para Euchlaena são por sua vez recessivohipostáticos aos gens de milho como se pode deduzir dos backcrosses para milho, nos quais êles não aparecem.

Tentaremos no futuro, seja simplesmente por autofecundação ou por cruzamentos entre o tipo 3 acima descrito e o milho Tunicata, obter um tal reagrupamento dos modificadores de Teosinte e de milho, que além de manutenção dos principais caracteristicos do tipo 3, reintroduzimos uma aproximaçăo na estrutura das inflorescências em hastes e galhos laterais.

Usaremos neste trabalho várias formas encontradas em milho indígena do triângulo central da América do Sul, isto é, na reglăo aproximadamente entre os Andes, a Bacia do Amazonas e a linha dos rios: Rio S. Fruncisco - Rio Grande Rio Paraná - Rio Pilcomaya, para introduzir mais alguns carateristicos, possivelmente primitivos: espiguetas multiflorais, espigas laterais ramificadas e ráchis flexivel.

Foram observados tres casos de tendéncia do funcionamento da flor estéril das espiguetas em espigas: no Tunicata Paulista e no Pipoca Paulista (BRIEGER), e em Cateto (DRUMOND, em Minas Gerais) além de uma variedade boliviana (CUTLER). A situação parece fisiológicamente pouco balançada, pois encontramos às vezes a flor superior, às vezes a flor inferior da espigueta e às vezes ambas desenvolvidas.

Como já mencionado, encontramos dois casos de espigas ramificadas, um em milho Cateto de $S$. Paudo e outro em milho Boliviano (Fig. 11). O tipo de ramificação no tipo ramo.so da coleçáo genética originária dos EE. UU. (EMERSON, etc., 1935) também às vezes é o mesmo, sem que se possa dizer que êste mesmo gen do cromosómio 7 fósse presente no citado milho indígena. Em todo caso, todos êstes tipos têm na espiga a mesuna modalidade da ramificação como na flecha: uma haste centra! ("central spike") e ramos laterais, todos muito juntos e separados das primeiras folhas ou palhas com gemas axilares por algumas folhas, sem galhos laterais.

A introdução de uma ráchis flexivel do milho indigena do triângulo central da América do Sul será provàvelmente bas- 
tante difícil, pois até hoje encontramos êste caraterístico sòmente esporàdicamente e sem poder fixá-lo genèticamente.

c) Finalmente, devemos mencionar um caraterístico de milho: a extrema incapacidade do milho de regenerar galhos que 亡ornam a planta completamente estéril quando as espigas, preformadas muito cedo, foram destruidas yor qualquer causa, como por exemplo um ataque de insetos. A diferença entre milho e teosinte neste sentido pode ser facilmente explicada pelo seguinte experimento. Plantas de milho pipoca com alguma perfilliaçăo e de Euchlaena, foram arrancadas quando tinham atingido cêrca de um têrço de seu tamanho, divididas e as partes plantadas de novo. Tanto a hasie principal como as perfiliações tinham neste momento já o seu sistema radicular bem desenvolvido de modo que elas pegaram fàcilmente. As partes de Euchlaena produziram novas perfiliações com facilidade e cada uma formou uma nova touceira. No milho, porém, tanto a haste principal como as perfiliaçóes desenvolveram-se inalteradamente como se elas tivessem ficado em conjunto. As flechas das perfiliaçōes eram parcialmente fêmeas e as espigas pequenas. Nenhuma nova perfiliaçāo foi formada.

Esta falta de qualquer regeneraçáo, combinada com a preformação das espigas, răo é nada vantajosa numa planta cultivada, e assim não parece provável que êste caráter tivesse sido escolhido e selecionado pelos indios durante a domesticação.

Usando a imaginação, podemos formalar a hipótese que o milho selvagem era uma planta bianual, que numa primeira fase de crescimento formou, alem do seu sistema radicular primário e secundário também os primórdios das suas inflorescências, passando depois por um periodo de repouso que podia ter correspondido a uma época de frio ou seca. Assim, pode-se explicar a preformação das espigas] Ns segunda época favorável, apenas um crescimento rápido sem novas diferenciaçóes permitiu imediatamente o florescimento das plantas.

\section{C) Explicação genética da reversão atavistica}

o tipo 3, descrito acima, encontrado em alguns individuos, difere tanto de Zea Mays como de Euchlaena Mexicana, e é ao mesmo tempo bem balançado, tendo uma organização que permitiria a sua sobrevivência e propagaçåo na natureza. As sementes, protegidas pelas glumas corneas, caem com facilidade e såo bastantes leves para serem disseminadas. 
Nós podemos interpretá-las como uma forma nova, ou como uma reversão para um tipo selvagem e ancestral.

A primeira interpretação seria a mesma que H. NILSON cleu à origem de Salix Laurina, uma nova espécie de acôroo com os sistemáticos especializados, que era conhecida dentro das coleções cultivadas e encontrada em alguns poucos lugares da natureza. Em experimentos, H. NILSON obteve formas idênticas como recombinação na segunda geração do cruzamento de Salix viminalis e $\mathbf{S}$. caprea. Em ambos os casos, Salix

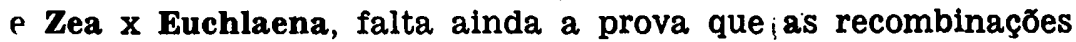
"extravagantes" já estão constantes. Salix Laurina é apenas conhecida como planta fêmea, não se conhecendo ainda a forna macho desta espécie, dióica como outras espécies do gênero Salix. Até hoje ela foi propagada apenas por estaquia. $O$ nosso tipo 3 foi obtido pela primeira vez no verão $\cdot 1943-44$ e as suas progénies obtidas por autofecundação serão estudadas êste ano 1944-45:

Os caraterísticos da Salix Laurina são diferentes daqueles de outras espécies do gênero, mas as diferenças não săo muito profundas.

O nosso tipo 3 , porém, difere tanto das espécies originais que os sistemáticos provàvelmente hesitariam de incluí-lo no gênero Zea ou Euchlaena se as plantas tivessem sido encontradas na natureza e não obtidas em experiencias genéticas. Mas o fato que mais me impressionou foi que êste tipo corresponde de modo inesperado às exigéncias formuladas no inicio dos meus estudos com respeito às espigas do milho selvagem. difícil imaginar que uma combinação de acaso de gens de duas espécies desse acidentalmente um fenótipo que se distingue muito dos pais e corresponde às exigências anteriormente formuladas para 0 ancestral do milho.

Mas antes de poder aceitar a interpretação do tipo 3 como uma reversão, devemos ainda fazer algumas considerações.

Como explicar genèticamente o reaparecimento do milho selvagem neste cruzamento e apenas depois de "backrosses" para Euchlaena? Estes "backcrosses" evidentemente tendem

a aumentar os gens modificadores de Euchlaena, tanto em número como em homozigotia, eliminando ao mesmo tempo em escala crescente os gens do milho domesticado. Não importa se nós considerarmos Euchlaena como uma espécie parente ou descendente de Zea Mays; ela deve ser portadora de um número grande de gens "selvagens"; ou homólogos ou até idênticos àqueles do milho selvagem. A nossa seleção era destinada a manter certos gens do milho, especialmente o gen Tu, 
considerado um gen remanescente, além da substituiçăo dos gens modificadores acumulados durante a domesticaçăo.

Temos dois argumentos em favor da consideração do tipo \& como uma reversáo e a melhor dproximaçăo ao milho selvagem:

1) Ele satisfaz na sua estrutura de espigas as exigências por nós anteriormente formuladas, sem repetir apenas as caracteristicas do milho ou de Euchlaena. 2) A reconstrução do milho selvagem nos "backcrosses" é genèticamente explicada de modo satisfatório, pela homologia comprovada de muitos gens das duas espécies, uma das quaís, Euchlaena, é uma planta selvagem.

\section{3 - A RECONSTRUÇAO DA DOMESTICAÇAO}

\section{A) 0 primeiro passo na domesticação}

Agora vamos inverter a nossa pergunta: se o tipo 3 é uma sproximação ou reconstrução do milho selvagem, como pode ter sido derivado dele durante o longo processo de domesticação o milho cultivado? Evidentemente é necessário uma substituição de numerosos gens que podem ser obtidos por mutacăo ou por hibridação. Assim, o gen tu do milho comum pode ser uma nova mutaçăo do gen Tu do milho selvagem ou pode ser introduzido por um cruzamento com Euchlaena ou Tripsacum. A primeira espécie contém com certeza um alele tu idéntico em todos os aspectos ao alele do milho comum, e as espécies do outro gênero contém provàvelmente o mesmo alele ou um alele correspondente.

Formulamos assim a hipotese que o primeiro passo na obtenção do milho cultivado do milho selvagem era um cruzamento com uma espécie de Tripsacum ou de um gênero parente. e inspecionamos os fatos para ver se podemos encontrar em milho característicos que não têm mais nenhum valor, mas que podem ser considerados como característicos introduzidos de Tripsacum.

Em Tripsacum os grãos são em geral protegidos pelas tapas e a ráchis em três lados, quando no lado dorsal a proteção é efetuada pela gluma externa que nesta região é muito dura e curva, como é melhor explicada pela fig. 14, A-C. As sementes são arredondadas, e ponteagudas onde era a base da barba. A:j inflorescênclas de Tripsacum (Fig. 15), são sempre fêmeas na base e machos na ponta, sendo a ráchis da primeira 
regiāo rígida e, quando madura, quebradiça e flexivel na part.e macho.

En milho do triângulo central da América do Sul encontramos frequentemente característicos que podemos chamar "tripsacóides". Entre as diferentes linhagens indigenas o "Pipoca Pontudo Paulista" é o mais extremo neste sentido. Na base das espiguetas, no seu pedúnculo ou mesmo no sabugo existe uma elevação em forma de meia lua, ás vezes muito pronunciada em cortes. este elemento estrutural está na mesma posição do que as "tapas" de Tripsacum e Euchlaena e encontraria uma explicação se considerado como tapa de tamanho reduzido.

As glumas do milho são em geral reduzidas a membranas finas. Mas não raramente encontramos no "Pipoca Pontudo Paulista" na gluma externa uma zona cornea na mesma regiăo que protege os grăos de Tripsacum.

A forma das sementes neste milho não é muito diferente daquela do Tripsacum australe, exceto que frequentemente a base da barba é transformada num bico muito longo.

Frequentemente o último têrço das espigas é diferente dos primeiros terços, sendo mais fino, flexivel, contendo ou flores machos isoladamente ou com tôdas as espiguetas machos.

A côr das sementes de Tripsacum australe é marron ou côr de terra. A mesma coloração é muito comum no milho indigena do Centro e Oeste do Brasil.

De outro lado, notamos em Tripsacum australe certas variações que talvez possam ser atribuidas, por sua vez, a uma transferência de poucos gens do milho. Entre os individuos que o Dr. CUTLER encontrou em Mato Grosso e que agora estão sendo estudados em Piracicaba, existe um individuo (Fig. 13 B e $D$, Fig. 14, D até E), que difere nos seguintes caraterísticos : um aumento de ramificação das inflorescências, grăos quase exclusivamente protegidos pelas glumas como em milho tunicata, sendo as tapas quase inexistentes, os estigmas brancos.

Também podemos explicar porque um híbrido entre um milho selvagem mais ou menos correspondendo ao nosso tipo 3 e Tripsacum oferece vantagens que induziram os indios a começar o seu cultivo e melhoramento.

Nós sabemos dos cruzamentos de milho (tutu) $x$ Euchlaena e $x$ Tripsacum que a fragilidade da ráquis é recessiva, sendo a espiga extremamente firme e rígida. De outro lado o conjunto dêsses gens de Euchlaena, no mínimo, suprime a camada de separaçâo na base dos grãos. Assim podemos supor que nos hibridos originais das duas espécies, milho selvagem e 
Tripsacum, ambos com espigas quebradiças de maneira difereni.e, aparece uma espiga rigida e não quebradiça, uma combinacão extremamente vantajosa para a colheita de uma planta cultivada, exigindo menos trabalho, dispensando o uso de cestas ou sacos bem fechados e causando menores perdas do que a. colheita de grăos pequenos e soltos.

Usando geraçóes posteriores póde-se combinar o gen tú de Tripsacum, reduzindo assim o tamanho das glumas, e muitos gens modificadores do milho selvagem para a reduça das "tapas", resultando grăos descobertos e sem ambos os elemenlos protetores. A grande vantagem destas alterações é evidente para todos que tentaram limpar os gráos tanto do milho tunicata como de Tripsacum.

Voltando agora mals uma vez à nossa pergunta como se deu a transformaçáo do milho selvagem, semelhante ao nosso tipo 3, para o milho cultivado, podemos agora dizer que o cruzamento com Tripsacum oferecia aos indios um material muito favorável para a seleçăo, sem a necessidade de esperar pacientemente o aparecimento raro de mutaçós favoráveis a domesticação.

A nossa hipótese naturalmente não é completamente nova. Uma vez que, como já dissemos, tódas as possibilidades da origem do milho já foram discutidas, isto não deve ser admirado, e basta citar os trabalhos de HARSHBERGER (1896, 1911) c COLLINS (1912, 1918, 1918, 1931) discutidos por MANGELSDORF and REEVES (1939, pp. 63-64).

\section{B - A hipótese da hibridação e 0 "inbreeding"}

Em seguida mencionaremos mais um ponto que me parece indicar claramente que uma hibridaçáo interespecifica faz parte da origem do milho cultivado. São os fatos geralmente reunidos sob o título "inbreeding and outbreeding", de acordo com " título do livro de EAST and JONES (1919) que reunia os fatos e as teorias pela primeira vez.

O milho comum contém sempre um grande númèro de fatores mendelianos que causam esterilidade ou letalidade quando homozigotos e são completamente inofensivos quando heterozigotos. Hes são responsáveis pelo fenômeno de "inbreeding" do milho numa forma tão extrema como em nenhuma outra espécie. A tentativa de explicar a acumulação de fatores de esterilidade e de letalidade unicamente como o efeito da reprodução cruzada, parece-me bastante forçada.

Plantas com métodos que proibem completamente a auto- 
fecundaçåo como a autoesterilidade em Anthirrinum, Petunia, Nicotiana, Brassica, etc., ou com uma separação dos sexos como em Canabis, Carica, etc., săo mais extremas na proibiçăo ou impossibilidade da autofecundaçáo. Quando nós conseguimos autofecundações, usando a pseudo-fertilldade genética ou fisiológica no primeiro caso e formas hermafroditas no segundo, notamos uma certa redução de vigor e 0 aparecimento de gens letais ou sub-letais. Porém, a redução de vigor nunca é tåo forte como no milho, e é geralmente possivel encontrar linhagers que são resistentes contra o "inbreeding", o que até hoje era impossivel no milho. De outro lado, teosinto, com uma organizaçăo muito semelhante no seu modo de reproduçăo a certas linhagens de milho, é imune contra 0 "inbreeding".

O milho comum porém é absolutamente diferente dos casos citados. Não existe evidentemente nenhuma linhagem de milho domesticado que fôsse imune contra a degeneração do "inbreeding.". Os geneticistas e práticos modernos năo conseguiram achar uma tal linhagem que teria muito valor prático. Dentro de muitas linhagens de milho cultivado pelos indios do Brasil, do Paraguai e da Bolívia, todos são extremamente sujeitos ao "inbreeding", e de tal modo que depois de uma ou (luas autofecundações a manutenção das linhagens é muitas vezes dificil ou impossivel. Sempre temos que registrar a presença de numerosos gens, inofensivos quando heterozigotos e prejurliciais quando homozigotos.

No milho năo existe um dispositivo eficiente que impeça uma autofecundação natural. Na maioria das linhagens o florescimento da flecha e da espiga coincide e quando năo há vento äemais o pólen pesado cal normalmente, alcançando as barbas do mesmo individuo e dos seus vizinhos no campo. Uma forte protandria ou protoginia poderia impedir uma autofecundaçáo, porém ela é sómente encontrada em algumas linhagens. Nenhum impedimento fisiológico existe com respeito a cruzamento entre individuos irmáos ou parentes de qualquer grau.

O modo de reprodução e a biologia da polonização em milho de nenhum modo podem explicar a acumulaçáo de tantas mutaçós, recessivas e prejudiciais, durante o longo processo de evoluçắo.

Quanto ao tamanho das populaçres de milho nas quais as mutaçóes deviam ter șido acumuladas, elas provàvelmente são formadas por alguns milhares de individuos com cêrca de 4 plantas por metro quadrado. De outro lado năo deveríamos esquecer que a eliminação é grande. Cada espiga contém 100 a 
400 grăos, mais ou menos, mas para a manutençăo da populaçâo apenas um dêles é o suficiente.

Assim, devemos constatar que não existe em milho um mecanismo contra a autofecundação e que também a seleção contra gens desfavoráveis será grande.

A teoria da hibridaçåo interespecifica oferece de outro lado um mecanismo bem diferente. um fato já conhecido nos tempos pré-mendelianos desde os trabalhos de KOLREUTER, que muitos hibridos interespecificos săo luxuriantes e providos de um vigor muito maior do que as espécies paternas. Igualmente sabemos que em muitos désses cruzamentos formas fracas e estereis aparecem nas gerações seguintes, a partir de $\mathbf{F 2}$.

Agora é preciso achar o mecanismo que agiu em favor da conservação justamente dos heterozigotos. A seleção natural dificilmente pode explicar a sua manutençăo exclusiva, mas náo devemos esquecer que se trata da filogenia de uma planta doméstica. bem provável que os hibridos iniciais com as suas combinaçōes de caracteres das duas espécies paternas e com o seu vigor pronunciado, impressionaram os indios e os induziram tentar selecionar a seu favor.

A existencia de uma tal seleçáo do lado dos indios náo pode ser posta em dúvida. Estudei nos últimos anos milho indigena da reglăo central da América do sul e sempre encontrei a mesma situaçăo: as linhagens eram relativamente uniformes cm relação a certos caracteres da espiga, da coloração dos gráos, etc., 0 que pode apenas ser explicado como consequencia de uma seleçăo anterior. Ao mesmo tempo êles sáo em geral multo produtivos e altamente heterozigotos com referência aos gens do vigor, sofrendo uma forte degeneraçáo quando autofecundados. Como os indios executam em detalhe a seleçăo de espigas e sementes para a plantaçăo, ainda hoje é desconhecido; sabemos apenas que os indios da referida regiáo, que nunca desenvolveram uma grande civilizaçáo, săo capazes de manter uma uniformidade de certos caraterísticos, combinada com uma alta heterozigotia em todos os gens de vigor executam, sem conhecimento de genética, um trabalho de seleçáo na direção postulada pelos melhoristas modernos: obtençăo do "milho hibrido".

Para resumir, não existe no milho um mecanismo que permita. a acumulaçáo de gens letais e de esterilidade durante a seleçáo natural e sôbre um prazo muito longo por um processo iento com a mutaçăo. Mas um cruzamento interespecifico daria imediatamente a combinaçáo heterozigota de gens letais e 
cie esterilidade balançada. Para a sua manutenção será necessário uma seleçáo inteligente e dirigida pelo homem, contrária à seleção natural, e que tenda a manter a heterozigotia. Verificamos que os índios ainda hoje são capazes de executar uma tal seleção.

\section{C - Esterilidade dos Homozigotos TuTu}

A hipótese da transferência de alguns gens de Tripsacum ao milho, em consequência do cruzamento, também pode explicar um outro fenómeno especial: a esterilidade das formas homozigotas TuTu do milho e a esterilidade parcial dos heterozigotos Tutu.

Sendo o gen Tunicata um gen "remanescente", seria dificil explicar porque justamente a combinação antiga e selvagem tornou-se estéril pelo acúmulo, durante a domesticação, de gens mutados. Mas a hipótese de cruzamentos implica que o gen Tu do milho selvagem foi substituido pelo gen tu da espécie tripsacóide. A seleção inicial dos indios consistiu em transferir, além do gen tu, outros gens da espécie tripsacóide para o milho. Os índios não faziam nenhum esfórço para harmonizar o gen $\mathrm{Tu}$ do milho selvagem com os gens transferidos da espécie tripsacoide e podia-se até supor que seu valor como variedade foi aumentado pela impossibilidade de cultivar e distribuir linhagens puras e homozigotas TuTu.

\section{D - A segunda fase da domesticação}

Ein resumo poderemos formular a nossa hipotese da ma.neira seguinte:

Existiu uma espécie de milho selvagem com inflorescêrcias que correspondem aproximadamente ao nosso tipo 3 (Fig. 10). As plantas possivelmente eram bisanuais, com uma adaptação a um periodo intercalado de repouso forçado. Esta espécio podia ainda existir hoje dentro das Andropogonaceae.

Esta espécie cruzou-se acidentalmente com uma espécie tripsacóide. Năo podemos dizer com certeza que se tratava de fato de uma das espécies hoje existentes de Tripsacum e também é provável que o cruzamento fôsse bastante raro, e os h!bridos obtidos ainda altamente estéreis, do mesmo modo como nos cruzamentos entre o milho moderno e Tripsacum dactyloides (MANGELSDORF and REEVES, 1939) e T. australe (GRANER e ADDISON, 1945). Mas os hibridos com as suas es. pigas não quebradiças interessaram os indios, os quais começaram o seu trabalho de domesticaçăo e melhoramento, selecio.. nando plantas de milho selvagem com alguns gens de Tripsa- 
cum combinando o gen tu e inflorescências rigidas que não mais soltaram os grãos. Além de aproveitar-se da segregaçãu inicial, os índios acumularam novas mutações, especialmente para o aumento do tamanho das espigas e grãos e do número de fileiras.

A forma ancestral tinha uma inflorescencia na qual as e:spiguetas foram distribuidas em lados opostos do eixo com umi filotaxia de 1:2. Com um aumento das fileiras, com ou sem desdobramento do número de espiguetas, a filotaxia apenás mudou, sem seguir porém a norma da filotaxia, e sem passar por $1: 3,2: 5$, etc. Havia transformações da espiral que às vo.. zes se dividiu em círculos ou verticilos de um número de espiguetas, todos na mesma altura. Simultaneamente se deu um. untrodução de uma nova simetria, um processo que nós encontramos não raramente em caules muito grossos como Cactacae, Euphorbiaceae e nos cones das Gymnospermas. A espiral foi subordinada a um arranjamento em fileiras longitudinais. Num indivíduo do gênero Cereus, com hastes de mais de $25 \mathrm{~cm}$. de diâmetro e mais do que 10 fileiras longitudinais podemos construir de fato várias espirais de fôlhas, sem saber qual a filotaxia real.

Em resumo ,existiu no início uma inflorescência com uma Iilotaxia $1: 2$, sendo as duas fileiras distribuidas nos lados opostos da ráquis. Posteriormente, com a seleção de espigas com uma ráquis mais grossa, manteve-se o arranjo rígido em fileiras longitudinais, e esta nova simetria se sobrepoz à filotaxia em espiral.

As vezes a espiga grossa do milho foi explicada como uma ¿nomalia patológica, isto é, uma forma de fasciação. Porém, órgãos fasciados são em geral muito mais irregulares do que as espigas de milho, revelando assim a sua natureza patológica e não balançada.

LANGHAM (1940) tentou reviver uma outra hipótese: que a espiga fôsse uma estrutura composta, devido à fusão de um súmero de galhos laterais com o galho principal ou "central spike".

Para evitar mal entendidos e confusão, devemos estudar em primeiro lugar o tipo de ramificação em milho e seus parentes.

Nós encontramos em Tripsacum australe (Fig. 14) a situacāo mais simples. Aqui as hastes principais terminam numa inflorescência pouco ramificada. A "central spike" tem em lado:s opostos as espiguetas, porém a primeira ou às vezes duas ou três espiguetas da base se desenvolvem mais, formando outras 
inflorescências. Exceto quanto a sua posição, a inflorescência centra não se distingue muito das laterais. A mesma haste que termina numa inflorescéncia assim ramificada produz outros ramos laterais da base das fôlhas. Estes, por sua vez, terminam acima da última fôlha em inflorescências que em geral não são mais ramificadas. Nas axilas da fôlha dêstes galhos aparecem mais tarde outros ramos, que também terminam em inflorescências, não ramificadas.

Este tipo de ramificação se repete também em Zea e Euchlaena. As inflorescências terminais em cima da última fôlha de hastes e ramos, podem ser simples ou ramificadas. Depois seguem alguns nós com fôlhas sem galhos laterais e depois um número variável de fôlhas com ramificações axilares. Quando a inflorescência terminal é ramificada, os ramos nã s são mais localizados nos lados opostos em duas fileiras, como em Tripsacum, mas formam verticilos ou seguem uma espiral Eles podem também ser por sua vez ramificados.

Esta estrutura é bem clara nas flechas, isto é, nas inflorescências terminais de hastes. (Fig. 3, A).

Nos ramos laterais da primeira ordem notamos em geral uma diferença: os internodios imediatamente em baixo da inflorescência terminal e que não produzem gemas axilares fi.. cam curtos. As ramificações secundárias dos nós mais baixos podem desenvolver-se. Isto é bem claro na Fig. $12 \mathrm{~A}$, de galhos laterais de milho com uma espiga não ramificada terminal, seguida por alguns internódios curtos e curvos, que são cobertos pelas palhas. Mais para baixo seguem algumas espigas secundárias, cada uma com seus nós portadores de palhas.

A Fig. 12, B representa as inflorescências laterais do híbrido milho $x$ teosinto. A principal diferença entre 12 A e B é que os galhos laterais da segunda ordem são ramificados também, com uma espiga terminal e outras espigas, representando ramos de terceira ordem.

Nẫo devemos confundir a ramificação dos galhos laterais e a ramificação da inflorescência terminal. Estes últimos sempre são localizados em cima da última fôlha e, quando há paIhas, incluidos em conjunto dentro das mesmas. Ramificações desta natureza em espigas são ilustradas do milho na Fig. 11 e de descendentes do híbrido Zea $x$ Euchlaena na Fig. 12C até E). Nas fotos é bem visível que, mesmo nestas espigas ramificadas, temos um "central spike", o qual agora é a espiga central com mais do que quatro fileiras.

Uma fusão verdadeira dentre estas inflorescências ou espigas ramificadas não encontrei nos muitos casos estudados em 
detalhe. As vẹes elas estão muito juntas e os seus grăos intercalados, como na Fig. 11, A, em consequência do espaço limitado dentro das palhas bastante fechadas.

Chegamos assim à conclusão que nem as formas, às vezes hereditárias, de espigas ramificadas, nem as formas correspondentes que aparecem no cruzamento Zea $\times$ Euchlaena, dăo suporte à hipótese da fusão. Sempre podemos encontrar mesmo nelas o eixo principal ("central spike") que já tem fileiras múltiplas. As inflorescencias, sejam elas espigas ou flechas, têm no seu eixo principal o número aumentado de fileiras quandc as laterais têm, com raras excepçōes, apenas 2 fileiras duplas com uma filotaxia de $1: 2$.

\section{4 - DISTRIBUIÇAOO GEOGRAFICA}

\section{A - A distribuição do milho indígena}

Conșiderando agora a questão geográfica, devemos distinguir três problemas: a distribuição do milho selvagem hipotético, a zona de origem do milho cultivado e finalmente os principais centros de domesticação mais intensiva.

Sóbre o primeiro ponto, nada podemos afirmar até agora. Considerando acima a possibilidade de se tratar de uma planta bienual e adatada a dois ciclos relativamente curtos, quelíamois especialmente pór em foco a possibilidade de que estas plantas eram adatadas a condições ecológicas completamente diferentes daquelas do milho cultivado. Esta possibilidade dificulta ainda mais qualquer especulação sôbre a verdadeira distribuiçăo do. suposto milho selvagem.

A zona da domesticaçáo inicial é um pouco mais fácil de deterninar. Devemos esperar que nesta zona encontraremos o maior número de caraterísticos primitivos ainda hoje em existencia. Esta zona é evidentemente o que nós chamamos o triángulo central da América do Sul, que se estende desde a base dos Andes no Oeste do Chaco no Paraguai até Mato Grosso no Brasil de um lado, até quase o Atlântico no Este. No Norte a zona é limitada pela bacia do Amazonas e no Sul pelos rios São Francisco, Paraná e Paraguai. BRIEGER e CUTLER (não publicado) fizeram um estudo detalhado do milho indigena desta vasta região e com resultados muito surpreendentes.

Notamos em primeiro lugar que há uma grande uniformidade sobbre tôda esta área, apesar de sua população índia muito espalhada e dividida em tribus, isoladas e inimigas umas das outras. 
Encontrámos com frequência, como já mencionámos acima, característicos primitivos como espigas finas com ráquis flexiveis, glumas bem desenvolvidas sem a presença do gen tunicata, grãos que se separam muito fácilmente do sabugo e que têm uma côr marron, em consequência de gens do pericárpio, aleurona e endosperma.

Além disso não são raros os vestígios de caracteres que podemos atribuir a influências de gens Tripsacum como flores machos na parte apical da espiga, restos das "tapas" e desenvolvimento de uma região córnea nas glumas, todos êstes sendo caracteres "tripsacóides" que parecem desconhecidos no milho indigena de outras regiões. Devemos esperar na região do cruzamento original um maior número de formas segregadas ainda existentes.

Nesta região existe hoje Tripsacum australe numa zona bastante limitada, isto é, no Oeste da base dos Andes, nas partes baixas da Bolivia e no Estado de Mato-Grosso, no Brasil, — no Chaco paraguáio. Assim parece possivel que esta seja a região mais exata na qual aconteceu o primeiro cruzamento entre o milho selvagem e Tripsacum que deu origem ao milho doméstico. interessante notar que MANGELSDORF and REEVES também chegaram à mesma conclusão, baseados em considerações bem diferentes. Da região original na base dos Andes o milho derivado dos híbridos iniciais espalhou-se sôbre o triângulo Central no Leste, sem sofrer muitas alterações. Ele subiu os Andes e na civilização dos Incas, no Perú e na Bolivia, êle continuou a desenvolver-se. Na parte andina da Bolivia e Perú a variação das formas cultivadas é bastante grande, mas agora sem o aparecimento dos caraterísticos de Tripsacum.

No outro lado do triângulo, na região costeira do Atlântico, desde as Antilhas até a Argentina, o tipo de milho predominante é o Cateto, um milho duro, intensamente colorido de laranja e que falta dentro do triângulo e nos Andes. A sua relação com os milhos do triângulo central de um lado e com os tipos cultivados nos Andes ainda é obscura. E possivel que êle se originasse num outro centro de domesticação no Uruguai ou Argentina. Ele combina a cór de muitos tipos indigenas do Triângulo central, com o amido duro e corneo do "Pipoca Pontudo".

Outros centros de domesticação com uma variação bastanle grande existem na América Central, no México e na Guatemala (MANGELSDORF and REEVES, 1939, MANGELSDORF and CAMERON, 1942). Mas a evolução do milho da América Central é um assunto sôbre o qual não quero ainda emitir uma opinião, pois me faltam conhecimentos detalhados sôbre o mi- 
Iho cultivado pelos índios nas partes do Norte e Noroeste da América do Sul sem os quais será impossivel estabelecer uma relação entre os milhos indígenas do Norte e Sul desta zona.

\section{B - Distribuição de gens}

Nas discussões sôbre a distribuição geográfica devemos nos referir apenas a milho que pode ser considerado como realmente indigena, pois não pode haver dúvida que, depois da colonização do Continente Americano pelos homens brancos, houve muita redistribuição secundária do milho.

Tomámos acima apenas em consideração os caraterísticos gerais dêstes tipos nativos de milho, e me parece prematuro entrar já em uma discussão detalhada sôbre a distribuição geográfica de determinados gens e de particularidades citológicas. A distribuição dos gens é um ponto que sòmente depois de um estudo detalhado poderá ser resolvido. As nossas análises do milho do triângulo central e do milho andino indicam - presença de muitos gens diferentes para a coloração da planta, palhas, glumas e grãos. Porém, comparações de fenótipos não servem para a execução destas comparações sendo necessário exécutar análises genéticas completas.

\section{C - Distribuição dos "knobs" nos cromossômios}

A principal peculiaridade citológica do milho até hoje estudada do ponto de vista da sua distribuição geográfica são os chamados "knobs", engrossamentos nos cromossômios que podem aparecer em determinados lugares dos mesmos. Longley (1939) descreveu dezoito lugares e Mangelsdorf and Cameron (1942) adicionaram três outros, sendo o número máximo de "knobs", até hoje observado de 16 por célula.

A distribuição geográfica dos "knobs" foi estudada por I.ongley (1938), Mangelsdorf and Cameron (1942) e Reeves (1944). Os resultados dêstes estudos demonstraram o seguinte: Na América Central desde a Colombia até o México o número médio de "knobs" por célula é alto (Guatemala : 9,2, México 8,0 e Colombia 7,0), mas êle é muito baixo nos Ándes (Equador 0,0, Perú 0.4 e Bolívia 0,3). Nos outros países das Américas encontramai números médios de "knobs", entre 2,0 e 5,5.

Os dados de Reeves (1944) referentes aos países da América do Sul devem, ao meu ver, ser tratados com cuidados, pela razáo seguinte: Do Brasil foram estudados 22 indivíduos de 
12 variedades, do Paraguay 10 plantas de 4 variedades, do Uruguai 1 planta de uma variedade e da Argentina 3 individuos de 3 variedades. Reeves não explica o que êle considera como "variedade". Mangelsdorf and Cameron consideram a progênie de cada espiga colhida no país de origem como uma "variedade" (1942 pg. 220). Este uso não me parece estar de acôrdo com as definições usuais do conceito de variedade. Além disso, a variabilidade de material do mesmo lugar é muito grande, no mínimo de acôrdo com os estudos de Mangelsdorf and Cameron (1942) sôbre o milho Guatemala. Não é também claro se os dados se referem a tipos hoje cultivados em maior escala, ou se se trata de número de "knobs" em milho, realmente indígena.

Os diferentes países são tratados de modo muito diferente. Do Perú e Bolívia foram estudados 31 e 13 "variedades" respectivamente, quando Brasil, Uruguai e Argentina são representados por 12,1 e 3 "variedades" apenas.

Reeves calcula a regressão linear entre o número médio de "knobs" por país e a distância dêste país da Guatemala, obtendo um valor correspodente de $t$ que é justamente maior do que $05 \%$ limite, ( $t$ calculado $=2,38$; $t$ esperado $=2,18$ ). Porém o modo de calcular estas distâncias me parece muito sumário. Qual é atualmente a distância mais curta terrestre de países do tamanho do Brasil ou dos Estados Unidos em relação a Guatemala ? A regressão seria tambem suficientemente grande quando fôsse tomada em consideração a variação do número de knobs em cada país ? Só depois da solução destas perguntas, e quando forem usadas apenas linhagens realmente indígenas dos diferentes países, as conclusões gerais de Reeves poderão ser consideradas como bastante seguras.

Chegamò assim à conclusão que por enquanto está comjrovado por Reeves um fato, aliás altamente importante : a frequência alta de "knobs" na América Central e a sua frequência baixa nos Andes de Bolívia-Perú.

Este fato parece ser relacionado com outro: a ausência de Euchlaena nos Andes e a sua frequência na América Central, especialmente em Guatemala.Mangelsdorf and Cameron "assume that chromosome knobs of present-day corn were derived from Tripsacum through teosinte and on that assumption the number of knobs becomes a rough measure of the amount of Tripsacoid admixture" (1942, pg. 223). Se compararmos esta conclusão com outra dos mesmos autores: "The combined evidence suggests that a South-American variety of corn hybridized with a species of Tripsacum admixture". (1942 pg. 
247-248) a situação torna-se ainda mais complicada. Evidentemente a chave do problema reside num estudo detalhado do número e da natureza dos "knobs" em Tripsacum.

O número básico de Tripsacum parece ser $n=18$. Longley (1924) inicialmente relatoù que tôdas as espécies por êle estudadas tinham $n=35$ cromossômios, um número que mais tarde foi corrigido para $n=36$. Mangelsdorf and Reeves consideram as formas de 72 cromossômios como auto-tetraplóides e as suas divisões meióticas parecem ser bastante irregulares (Longley 1924, Mangelsdorf and Reeves, 1939). Longley (1937, Mangelsdorf and Reeves (1939) encontraram $\mathrm{n}=18 \mathrm{em} \mathbf{T}$. floridanum, e em algumas formas de $T$. dactyloides e Graner e Addison (1945) determinaram o mesmo número em $\mathbf{T}$. australe.

Longley $(1937,1941)$ deu um desenho esquemático de $\mathbf{T}$. floridanum com "knobs" terminais em todos os 18 cromossômios, quando Graner e Addison (1945) não encontraram "knobs" em T. australe. Mangelsdorf and Reeves (1939) não fizeram referência alguma sôbre o número dos "knobs" nos híbridos de milho e Tripsacum.

Assim me parece indispensável esperar os resultados de uma análise bem mais completa dos citologistas de tôdas as espécies dêste gênero. Numa publicação recente Cutler and Anderson (1941) distinguem sete espécies: $\mathbf{T}$. floridanum e $\mathbf{T}$. dactyloides são encontrados nos Estados Unidos e T. lanceolatum desde o Arizona até Guatemala; T. Fasciculatum e T. pilosum são espécies da América Central. Finalmente devemos mencionar $\mathbf{T}$. latifolium, encontrado tanto na América Central como no Norte da América do Sul e T. australe. A área da última espécie, que anteriormente era considerada apenas como pertencendo a T. dactyloides, é muito extensa e os autores citam lugares do Paraguai, Bolívia, Brasil, Equador, Columbia e Guiana Británica.

A situação torna-se ainda mais complicada se incluirmos em nossas considerações também os B-cromossômios de rillho que recentemente foram considerados por Randolph (1941, pg. 612) como sendo talvez derivados de cromossômios de Tripsacum.

Se aceitarmos provisóriamente os resultados obtidos, a frequência dos "knobs" em Zea e Tripsacum é paralela: poucos ou nenhum "knob" são encontrados na América do Sul em ambos os gêneros, e muitos "knobs" na América Central e mais para o Norte. 


\section{5 - CONCLUSOEES}

1) Discutindo resumidamente as relaçōes entre milho e teosinto náo podemos achar provas convincentes nem a favor da hipótese de Ascherson que o milho é um descendente do outro gênero,nem da hipótese de Mangelsdorf and Reeves que 0 teosinto é um descendente do milho Zea Mays e Euchlaena mexicana são espécies muito parentes botânica, genética e citologicamente, mas não dispomos ainda de material suficiente para definir de modo convincente o tipo do parentesco.

2) Aceitamos com MANGELSDORF and REEVES a antiga hipotese de ST. HILAIRE que o milho tunicata é a forma, hoje existente, que mais se aproxima ainda ao milho antigo selvagem. Fm vista da grande variabilidade fenotípica das plantas tunicata (BRIEGER, 1943, 1944) náo podemos esperar que o fenotipo mais comum hoje fósse o fenótipo dêste "wild relic gene" na fase anterior à domesticação. Assim foi a nossa primeira tarefa tentar a reconstruçăo fenotípica e genotípica da forma tunicata selvagem.

3) MANGELSDORF and REEVES (1939) formularam a hipótese que a forma selvagem TuTu tinha a flecha transformacia em órgāo hermafrondito. Como demonstrámos (BRIEGER, 1943) em formas mais extremas do que aquelas obtidas e fotografadas pelos dois autores mencionados, êste tipo não explica a origem do órgão mais importante do milho doméstico: a espiga. De fato, as plantas em questăo não só mantêm a sua espiga lateral mas o eixo central ("central spike") da flecha é transformado em uma segunda espiga.

4) Como orientação para os meus trabalhos, estabeleci em primeiro lugar as exigências minimas, que devem ser satisfeitas para reduzir a espiga do milho cultivado a um órgão primitivo $\mathrm{P}$ adatado à vida selvagem:

número de fileiras proteçáo das sementes separação dos grãos

$$
\begin{array}{ll}
: 2 \times 1=2 & 2 \times 2=4 \\
: \text { pela ráquis } & \text { pelas glumas }
\end{array}
$$$$
\text { : ráquis quebradiça grãos se separan- }
$$
do da ráquis

A primeira série de caracteres é encontrada nos gêneros Tripsacum e Euchlaena. Caraterísticos aproximando-se da segunda soluçåo se encontram separadamente espalhados em algumas linhagens de milho.

Resolvi tentar reproduzir uma forma selvagem da constituição TuTu, combinando com ela os modificadores "selva- 
gens" necessários. Uma vez que parece que elas foram perdiclas na domesticação, foi necessário substituir êstes gens perdidos em milho pelos gens análogos de uma espécie selvagem, sendo Euchlaena mexicana a única espécie que pode ser usada para dar híbridos razoavelmente férteis.

A seleção teve um sucesso inesperado e uma forma foi ob¿ida já no segundo "backcross" para Euchlaena, que era bastante diferente desta espécie, satisfazendo tôdas as exigências tstabelecidas sob o ponto 4 (Fig. 10).

6) Futuros estudos, já encaminhados, devem decidir se poderemos ir mais para a frente, introduzindo neste milho selvagem, reconstruido, os seguintes caraterísticos, todos observados no milho indígena do triângulo central da América do Sul: dois ou mais grãos por espigueta, espiga lateral ramificada, flecha hermafrodita, ou então, em resumo, uma estrutura idêntica das inflorescências, lateral e terminal.

7) Em seguida invertí a pergunta e resolví decidir como desta forma hipotética selvagem pode-se chegar a forma cultivada de milho. A suposição do acúmulo de mutações parece um pouco forçada, porém um cruzamento inicial com uma espécie tripsacóide, se razoavelmente fértil, oferecia imediatamente um amplo material para a seleção. Assim, supomos que nesta espécie tripsacóide contribui o gen tu para a redução das glumas, e que dois modos de separação, na base dos grãos e na base dos internódios, se contrabalançaram de modo a dar espigas não quebradiças.

A teoria da hibridação inicial na passagem do milho selvagem para o milho cultivado explica também dois outros fenômenos, o efeito do "inbreeding and outbreeding" e a esterilidade dos homozigotos TuTu.

8) Como suporte à teoria da origem híbrida do milho cultivado podemos citar o aparecimento no milho indígena do centro da América do Sul de carateristicos que correspondem aos caracteres do hipotético milho selvagem ou de Tripsacum. Igualmente, caracteres do milho selvagem foram encontrados em Tripsacum australe de Mato-Grosso.

9) Frormulámos a hipótese de que a origem do milho doméstico se deu na região que hoje pertence ao Chaco, Bolivia e Paraguai e à parte leste do Estado de Mato-Grosso. Aqui o milho selvagem, a distribuição geográfica do qual ainda é obscura, ๔ uma espécie "tripsacóide", talvez o próprio Tripsacum australe, foram cruzados, e iniciada pelos índios a seleção de domesticação.

10) Depois se desenvolveram dois centros de domestica- 
ção: um na parte baixa, no triânguio central da América do Sul, entre os Andes, o vale do Amazonas e o vale dos rios são Francisco, Grande e Paraguai, e outro nos Andes da Bolívia e Perú.

O; dois centros de domesticação do México e do Paraguai, o último descrito recentemente por MANGELSDORF and CAMERON (1942) parecem bem separados dos primeiros centros.

A zona do Cateto finalmente ocupa a área costeira desde as Antilhas até a Argentina. Talvez o Cateto originou-se na parte sul-este do triângulo central (S. Paulo-Goiaz), mas havia migrações tanto na direção sul-norte como norte para sul.

11) Um estudo da literatura referente à distribuição geográfica dos "knobs" nos cromossômios, indica a existência de duas regiôes principais: a zona Andina (Bolívia e Perú) com poucos "knobs" e a zona da América Central (México e Guatemala) com muitos "knobs" por célula. Uma decisão sôbre a situação nas partes restantes depende de novas análises, especialmeente das espécies de Tripsacum e do milho do triângulo Central, estudos êstes já iniciados.

\section{ABSTRACT}

1) It may seem rather strange that, in spite of the efforts of a considerable number of scientists, the problem of the origin of indian corn or maize still has remained an open question. There are no fossil remains or archaeological relics except those which are quite identical with types still existing. (Fig. 1). The main difficulty in finding the wild ancestor- which may still exist - results from the fact that it has been somewhat difficult to decide what it should be like and also where to look for it.

2) There is no need to discuss the literature since an excellent review has recently been published by MANGELSDORF and REEVES (1939). It may be sufficient to state that there are basically two hypotheses, that of ST. HILAIRE (1829) who considered Brazilian pod corn as the nearest relative of wild corn still existing, and that of ASCHERSON (1875) who considered Euchlaena from Central America as the wild ancestor of corn. Later hypotheses represent or variants of these two hypotineses or of other concepts, howewer generally with neither disproving their predecessors nor showing why the new hypotheses were better than the older ones. Since nearly all possible combinations of ideas have thus been put forward, it har- 
dly seems possible to find something theoretically new, while it is essential first to produce new facts.

3) The studies about the origin of maize received a new impulse from MANGELSDORF and REEVES's experimental work on both Zea-Tripsacum and Zea-Euchlaena hybrids. Independently I started experiments in 1937 with the hope that new results might be obtained when using South American material. Having lost priority in some respects I decided to withold publication untill now, when I can put forward more concise ideas about the origin of maize, based on a new experimental reconstruction of the "wild type".

4) The two main aspects of MANGELSDORF and REEVES nypothesis are discussed. We agree with the authors that ST. HILAIRE's theory is probably correct in so far as the tunicata gene is a wild type relic gene, but cannot accept the reconstruction of wild corn as a homozygous pod corn with a hermaphroditic tassel. As shown experimentally (Fig. 2-3) these tassels have their central spike transformed into a terminal, many rowed ear with a flexible rachis, while possessing at the same time the lateral ear. Thus no explanation is given of the origin of the corn ear, which is the main feature of cultivated corn (BRIEGER, 1943). The second part of the hypothesis referring to the origin of Euchlaena from corn, inverting thus ASCHERSON's theory, cannot be accepted for several reasons, stated in some detail. The data at hand justify only the conclusion that both genera, Euchlaena and Zea, are related, and there is as little proof for considering the former as ancestor of the latter as there is for the new inverse theory.

5) The analysis of indigenous corn, which will be published in detail by BRIEGER and CUTLER, showed several very primitive characters, but no type was found which was in all characters sufficiently primitive. A genetical analysis of Paulista Pod Corn showed that it contains the same gene as other tunicates, in the IV chromosome, the segregation being complicated by a new gametophyte factor Ga3. The full results of this analysis shall be published elsewhere. (BRIEGER). Selection experiments with Paulista Pod Corn showed that no approximation to a wild ancestor may be obtained when limiting the studies to pure corn. Thus it seemed necessary to substitute "domesticated" by "wild type" modifiers, and the only means for achieving this substitution are hybridizations with Euchlaena. These hybrids have now been analysed init fourth generation, including backcrosses, and, again, the full data will be published elsewhere, by BRIEGER and ADDISON. In 
the present publication three forms obtained will be described only, which represent an approximation to wild type corn.

6) Before entering howewer into detail, some arguments against ST. HILAIRE's theory must be mentioned. The premendelian argument, referring to the instability of this character, is explained by the fact that all fertile pod corn plants are heterozygous for the dominant $\mathrm{Tu}$ factor. But the sterility of the homozygous TuTu, which phenotypically cannot be identified, is still unexplained. The most important argument against the acceptance of the Tunicata factor as wild type relic gene was removed recently by CUTLER (not yet published) who showed that this type has been preserved for centuries by the Bolivian indians as a mystical "medicine".

7) The main botanical requirements for transforming the corn ear into a wild type structure are stated, and alternative solutions given. One series of these characters are found in Tripsacum and Euchlaena : 2 rows on opposite sides of the rachis, protection of the grains by scales, fragility of the rachis. There remains the other alternative : 4 rows, possibly forming double rows of female and male spikelets, protection of kemels by their glumes, separation of grains at their base from the cob which is thin and flexible.

8) Three successive stages in the reconstruction of wild corn, obtained experimentally, are discussed and illustrated, all characterized by the presence of the Tu gene.

a) The structure of the F1 hybrids has already been described in 1943. The main features of the Tunicata hybrids (Fig. -8), when compared with non-tunicate hybrids (Fig. 5-6), consist in the absence of scaly protections, the fragility of the rachis and finally the differentiation of the double rows into one male and one female spikelet. As has been pointed out, these characters represent new phenotypic effects of the tunicate factor which do not appear in the presence of pure maize modifiers.

b) The next step was observed among the first backcross to teosinte (Fig. 9). As shown in the photography, Fig. $9 \mathrm{D}$, the features are essencially those of the F1 plants, except that the rachis is more teosinte like, with longer internodes, irregular four-row-arrangement and a complete fragility on the nodes.

c) In the next generation a completely new type appeared (Fig. 10) which resembles neither corn nor teosinte, mainly in consequence of one character: the rachis is thin and flexible and not fragile, while the grains have an abscission layer at 
the base, The medium sized, pointed, brownish and hard granis are protected by their well developed corneous glumes.

This last form may not yet be the nearest approach to a wild grass, and I shall try in further experiments to introduce other changes such as an increase of fertile flowers per spikelet, the reduction of difference between terminal and lateral inflorescences, etc.. But the nature of the atavistic reversion is alveadwy such that it alters considerably our expectation when looking for a still existing wild ancestor of corn.

9) The next step in our deductions must now consist in an ieversion of our question. We must now explain how we may obtain domesticated corn, starting from a hypothetical wild plant, similar to type c. Of the several changes which must have been necessary to attract the attention of the Indians, the following two seem to me the most important: the disappearance of all abscission layers and the reduction of the glumes. This inay have been brought about by an accumulation of mutations. But it seems much more probable to assume that some crossirg with a tripsacoid grass or even with Tripsacum australe may have been responsible. In such a cross, the two types of abscission layer would be counterbalanced as shown by the F1hybrids of corn, Tripsacum and Euchlaena. Furthermore in later generations a tu-allele of Tripsacum may become homozygous and substitute the wild tunicate factor. of corn.

The hypothesis of a hybrid origin of cultivated corn is not compietely new, but has been discussed already by HARSHBERGER and COLLINS. Our hypothesis differs from that of MANGELSDORF and REEVES who assume that crosses with Tripsacum are responsible only for some features of Cenral and North American corn.

h

10) The following arguments give indirects evidence in support of our hypothesis:

a) Several characters have been observed in indigenous corn from the central region of South America, which may be interpreted as "tripsacoid".

b) Equally "zeoid" characters seem to be present in Tripsacum australe of central South -America.

c) A system of unbalanced factors, combined by the intergeneric cross, may be responsible for the sterility of the wild type tunicata factor when homozygous, a result of the action of modifiers, brought in from Tripsacum together with the tu-allele.

d) The hybrid theory may explain satisfactorily the presence of so many lethals and semilethals, responsible for the 
phenomenon of inbreeding in cultivated corn. It must be emphasized that corn does not possess any efficient mechanism to prevent crossing and which could explain the accumulation of these mutants during the evolutionary process. Teosinte which has about the same mechanism of sexual reproduction has not accumulated such genes, nor self-sterlle plants in spite of their pronounced preference for crossing.

11) The second most important step in domestication must have consisted in transforming a four rowed ear into an ear with many rows. The fusion theory, recently revived by LANGHAM is rejected. What happened evidently; just as in succuient plants (Cactus) or in cones os Gymnosperms, is that there has been a change in phyllotaxy and a symmetry of longitudinal rows superimposed on the original spiral arrangement.

12) The geographical distribution of indigenous corn in South America has been discussed. So far, we may distinguish three zones. The most primitive corn appears in the central Jowlands of what I call the Central Triangle of South America: east of the Andies, south of the Amazone-Basin, Northwest of a line formed by the rivers Săo Francisco-Paraná and inclucing the Paraguay-Basin. The uniformity of the types found in this extremely large zone is astonishing (BRIEGER and CUTLER). To the west, there is the well known Andian region, characterized by a large number of extremely diverse types from small pop corn to large Cuszco, from soft starch to modified sweet corn, from large cylindrical ears to small round ears, etc.. The third region extends along the atlantic coast in the east, from the Caribean Sea to the Argentine, and is characterized by Cateto, an orange hard flint corn.

The Andean types must have been obtained very early, and undoubtedly are the result of the intense Inca agriculture. The Cateto type may be obtained easily by crosses, for instance, of "Sro Paulo Pointed Pop" to some orange soft corn of the central region.

The relation of these three South American zones to Central and North America are not discussed, and it seems esseni, ial first to study the intermediate region of Ecuador, Colonibia and Venezuela.

The geograprical distribution of chromosome knobs is rapidly discussed; but it seems that no conclusions can be drawn before a large number of Tripsacum species has been analysed. 


\section{LITERATURA}

ANDERSON, E. and F. G. BLANCHARD. 1942 - Prehtstoric maize from Canion del Muerto Am. Journal Bot. 29 : 832-835.

ARNASON, J. T. 1936 - Cytogenetics of hybrids between Zea Mays and Euchlaena Mexicana - Genetics 21-: 40-60.

ASCHERSON, E. 1875 - Uber Euchlaena Mexicana Schrad. Bit. Ver. Brandenburg. $17: 76-80$.

BRIEGER, F. G. 1943 - Origem do milho. "Semana da Genética". Rev. Agr. 18 : 409-418.

HRIEGER, F. G. 1944 - Considerações sôbre o mecanismo da evolução. Anais da Escola Sup. de Agric. "Luiz de Queiroz": 1 : 177-211.

BEADLE, G. W. 1932a - Studies of Echlaena and its hybridis with Zea I. Chromosome behavior. Zeitsch. Ind. Vererb. 62 : 291-304.

BEADLE, G. W. 1932b - The relation of crossing over to cromossome association in Zea-Euclaena hybrids. Genetics. 17 : 487-500.

COLLINS, G. N. 1912 - Origin of maize. Journ. Wash. Acad. Sc. $8: 42-43$.

COLLINS, G. N. 1923 - An ear of prehistoric maize that resembles the fossil form, Zea antiqua. Journal Heredity 14 : 61-64.

COLLINS, G. N. 1931 - The phylogeny of maize. Bull. Torrery Bot. Club. 57 : 199-210.

COLLINS, G. N. and J. H. KEMPTON, 120 - A teosinte-maize hybrid. Journ. Agr. Res. 19 : 1-37.

CUTLER, H. C. and E. ANDERSON 1941 - A preliminary survey of the genus Tripsacum An. Missouri Bot. Garden 28 : 249-269.

FMERSON, R. A. and G. W. BEADLE, 1932 - Studies of Euchlaena and its hybrids with Zea II. Crossing over. Zeitsch. Ind. Vereb. 62 : 305-312.

EMERSON, R. A., G. W. BEADLE and A. FRASER, $1935-A$ summary of linkage studies in maize. Cornell Agr. Exp. Sta. Mem. 180 : 1-83. 
GRANER, E. A. and G. O. ADDISON, 1944 - Meiosis em Tripsacum australe. Anais da Escola Sup. de Agric. "Luiz de Queiroz" 1 : 213-224.

HARSHBERGER, J, W. 1893 - Maize, a botanical and economic study: Contr. Bot. Lab. Univers. Pa. 1 : 75-202.

HARSHBERGER, J. W. 1941 - An unusual form. of maize. Proc. Delaware Inst. Sc 6 : 49-53.

KEMPTON, J. N. and W. POPNOE. 1937 - Teosinte in Guatemala. Carnegie Inst. Wash. Publ. 483 : 199-218.

LANGHAM, D. G. 1940 - The inheritance of intergeneric differences in Zea Euchlaena hybrids. Genetics 25 : 88-108. (Abstract in Genetics 193924 : 78).

IONGLEY, A. E. 1924 - Chromosomes in maize and maize relatives. Jorn. Agr. Res. 54 : 835-862.

I,ONGLEY, A. E.. 1937 - Morphological characters of teosinte chromosomes. Journ. Agr. Res. 54: 835-862.

LONGLEY, A. E. 1938 - Chromosomes of maize from North American Indians. Journ. Agr. Res. 56 : 177-195.

LONGLEY, A. E. 1941 - Knob positions on teosinte chromosomes. Journ. Agr. Res. 62: 401-413.

IMANCELSDORF, P. C. and J. W. CAMERON. 1942 - Western Guatemala, secondary center of origin of cultivated maize varieties. Bot. Museum Leaf. Harvard Univers. 10 : 217-312.

IMANGELSDORF, P. C. and R. G. REEVES. 1938 - The origin of maize. Proc. Nat. Acad, Sc. (U.S.A.) 24 : 303-312

MANGELSDORF, P. C. and R. G. REEVES. 1939 - The origin of Indian Corn and its relatives. Texas Agr. Exp. Sta. Bull. $574: 1-315$.

MANGELSDORF, P. C. and R. G. REEVES. 19931 - Hybridization of maize, Tripsacum and Euchlaena. Journ. Heredity. 22 : 329-343.

NILSON, H. N. 1928 - Salise Laurina. Die Lösung einer mehrals 100 jährigen phylogenetichen streitfrage Vhl. Fys. Sakk. Handl. N. F. 39 : 1-89.

O'MARA, J. G. 1942 - A cytogenetic study of Zea and Euchlaena. Univ. Missouri. Res. Bull. 341 :1-16.

RANDOLPH, L. G. 1941 - Genetic characters of the B Chromosomes in Maize. Genetics 26 : 608-631. 
KEEVES, R. G. and P. C. MANGELSDORF. 1942 - A proposed taxonomic change in the tribe Maydene. Am. Journ. Bot. 19 : 815-817.

REEVES R. G. 1944 - Chromosome knobs in relation to the oxigin of maize. Genetics 29 : 141-147.

SAINT-HILAIRE, A. de 1938 - Lettre sur une varieté remarquable de mais du Bresil. An. Sc. Nat. 16 : 143-145.

T'AVCAN, A. 1935 - Beitrag zur Vererbung der Kornreihenzahl an Maiskolben. Zeitschr. f. Züchtungk, $20: 307-442$.

\section{EXPLICAÇÃO DAS FIGURAS}

FIG. 1 - A) Fotografias de três reproduções em barro de milho peruano (Peabody Museu, segundo Mangelsdorf and Reeves, 1939). B) Seis espigas de milho "pigmeo" do lago Titicaca. (Segundo O. F. Cook, Rep. Smithsonian Inst. 1931).

FIG. 2 - A e B) Plantas de milho normal. C e D) Plantas de milho Tunicata (Tutu) com flechas hermafroditas.

FIG. 3 - A) Flecha e as duas espigas de plantas normais. B e C) Flexas de plantas Tutu, da mesma família. A direita, a flecha em posição normal e à esquerda sem fólhas e abertas. A seta $1 \mathrm{em} \mathrm{C}$ indica a posição da espiga lateral, puluco desenvolvida, e as setas $2 \mathrm{em} \mathrm{C} \mathrm{e} 3 \mathrm{em} \mathrm{B}$ indicam as espigas terminais, formadas pelo eixo central da inflorescência.

FIG. 4 - A e B) Espigas jovens de Euchlaena mexicana. C) Duas espigas jovens de milho.

FIG. 5 - Espigas jovens do híbrido $F 1$ (milho normal $x$ teosinto) em florescimento. A) Uma espiga vista de três lados diferentes. B) Duas espigas em vista frontal. C) As mesmas duas espigas em vista lateral.

FIG. 6 - Espigas maduras do híbrido $F 1$ (milho normal $\mathrm{x}$ teosinto). A até D) Seis espigas, vistas de frente, (A e C) e vistas de lado, (B e D). E) Inflorescencia completa. 
FIG. 7 - Espigas jovens do híbrido F1 (milho tunicata palllista $\mathrm{x}$ teosinto) em florescimento. A) Uma espiga vista de dois lados opostos. B) Três espigas, e no lado direito, três pares de espiguetas.

FIG. 8 - Espigas maduras do hibrido F1 (milho tunicata Paulista x teosinto) A) Inflorescência completa. B e C) Espigas quebradiças, os nós isolados e vistos de lado (B) ou de cima (C). D) Espigas inteiras com indicação da separação dos grãos do sabugo (seta).

FIG. 9 - Espigas de várias plantas do primeiro "backcross" do hibrido (milho tunicata paulista $\mathrm{x}$ teosinto). A até $\mathrm{D}$ ) Plantas tunicata Tutu. E e F) Plantas normais tutu.

FIG. 10 - Reconstrução do milho selvagem. A e D) Espiga de frente. B) Espiga vista de lado. C e E) Esplga com grãos maduros e soltos.

FIG. 11 - A e B) Espigas ramificadas de milho boliviano, em A um pouco aberto e em B as partes separadas. C) Espiga ramificada de milho Cateto.

FIG. 12 - A) Galho lateral fêmea ramificado do milho normal. B) Inflorescência lateral do hibrido (milho $\mathrm{x}$ teosinto;. $\mathrm{C}$ até E) Inflorescência de plantas tunicata de F2 (milho $\mathrm{x}$ teosinto); o eixo central da flecha indicada como "terminal" em C e E; as inflorescências terminais do galho fêmea indicado com "terminal lateral", e as espigas de segunda ordem como "lateral".

FIG. 13 - Parte da inflorescência de Tripsacum australe, madura, (A e B) e jovem (C e D). A e C pertencem ao tipo T1, e B e D ao tipo T3.

FIG. 14 - Inflorescência de Tripsacum australe T1 (A até $C$ ) e T3 (D até E) A e D) Inflorescências terminais de hastes principais. B e E) Inflorescências nos galhos laterais da primeira ordem. C e F) Inflorescências nos galhos laterais de segunda ordem. 


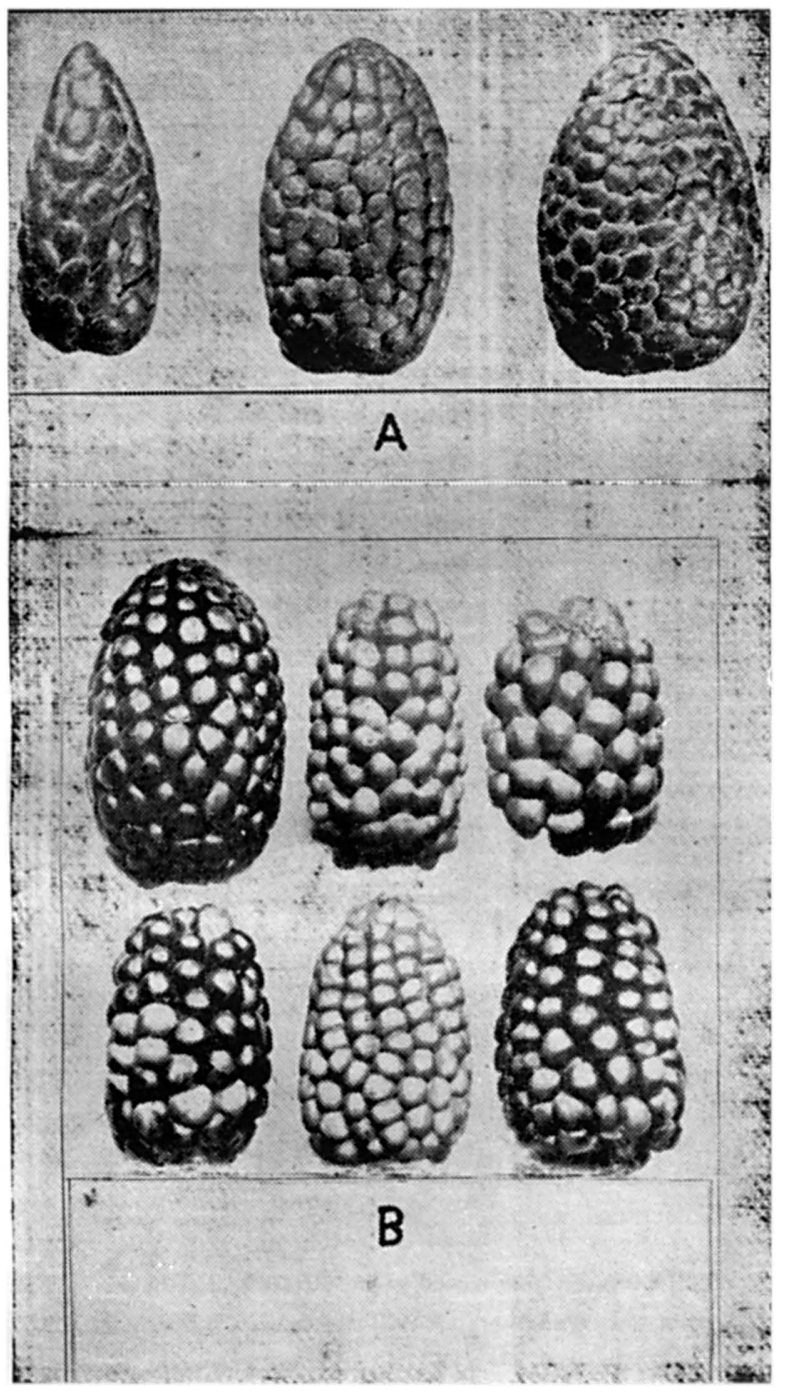

Fig. 1 


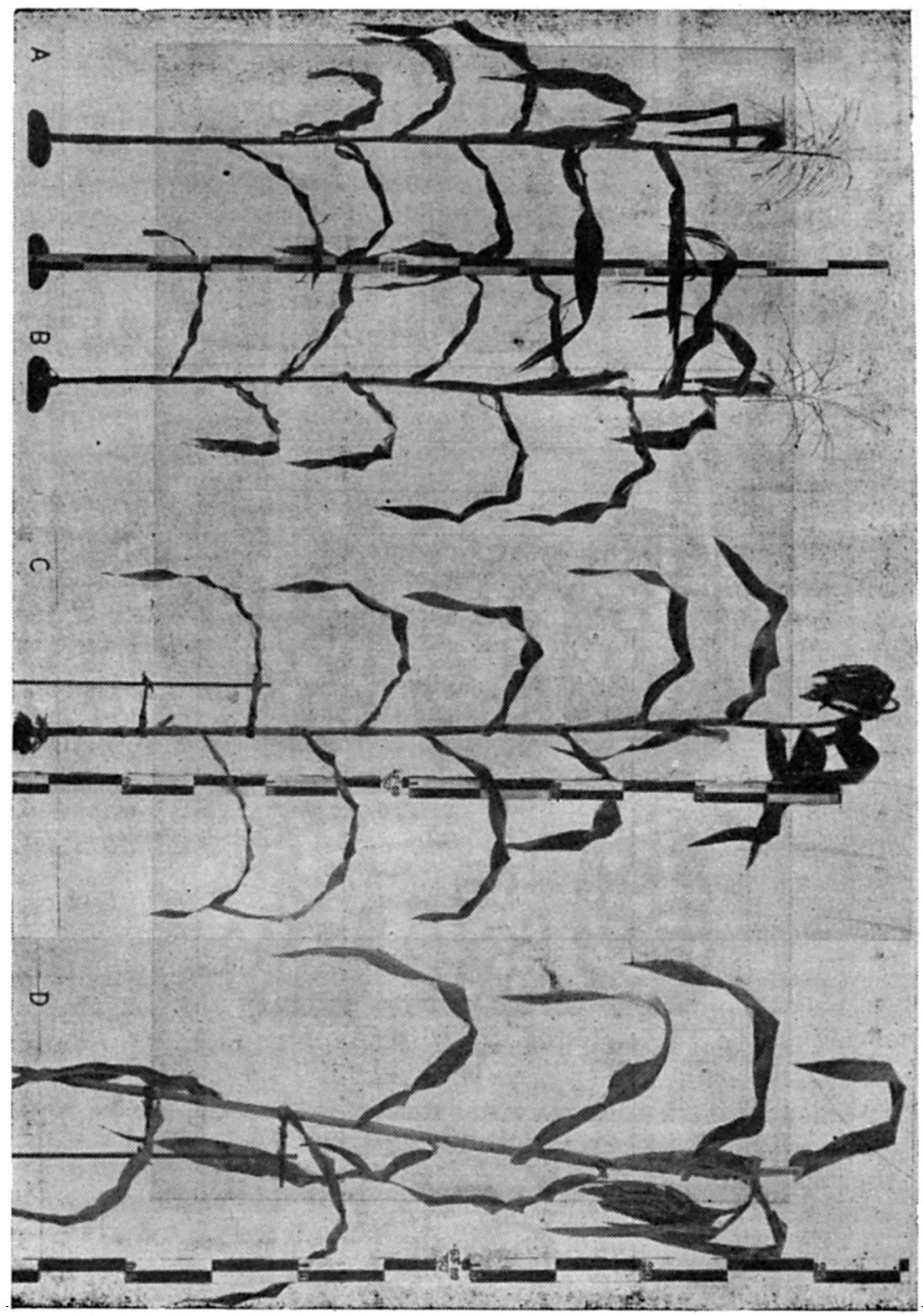

F'ig. 2 

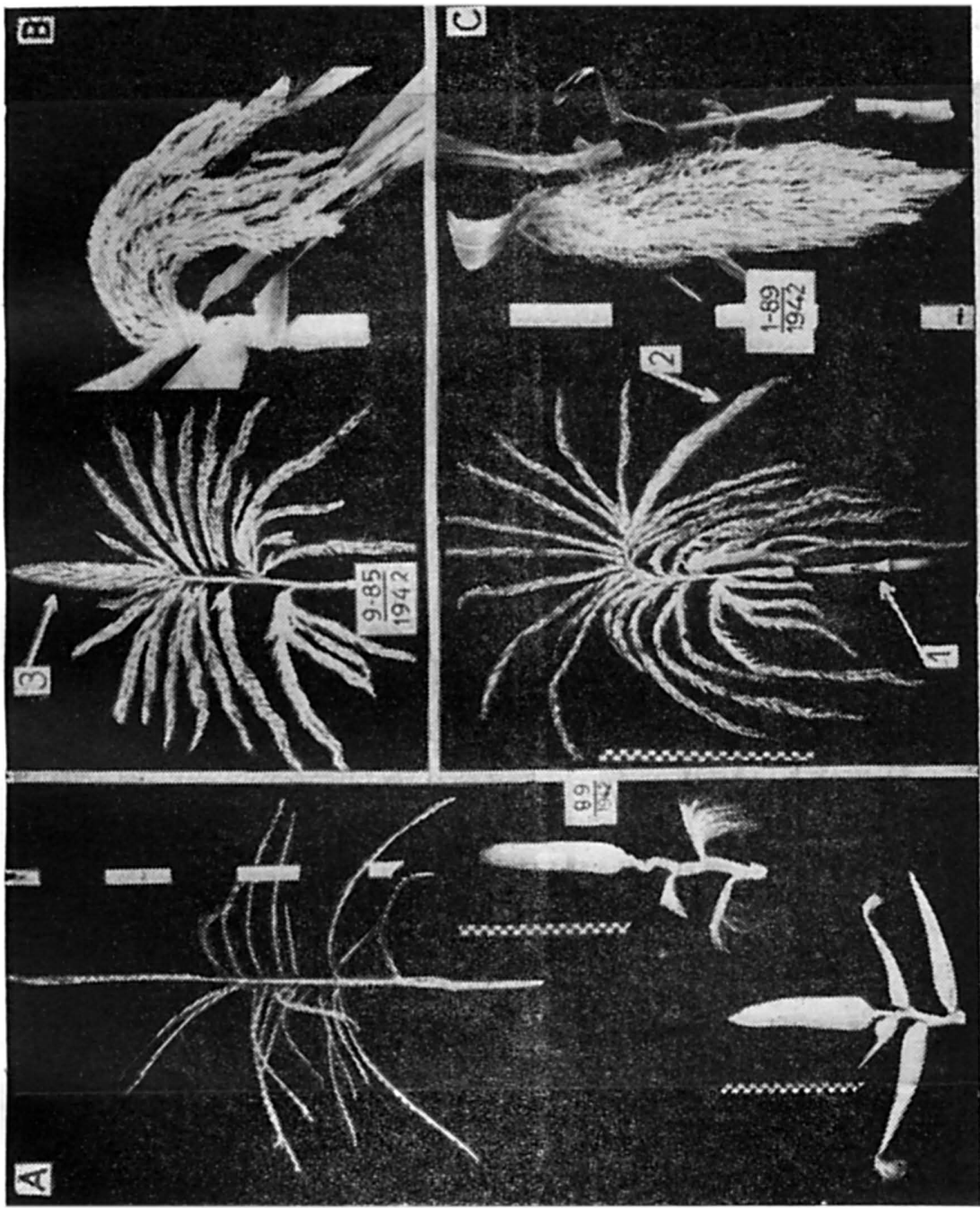

Fig. 3 


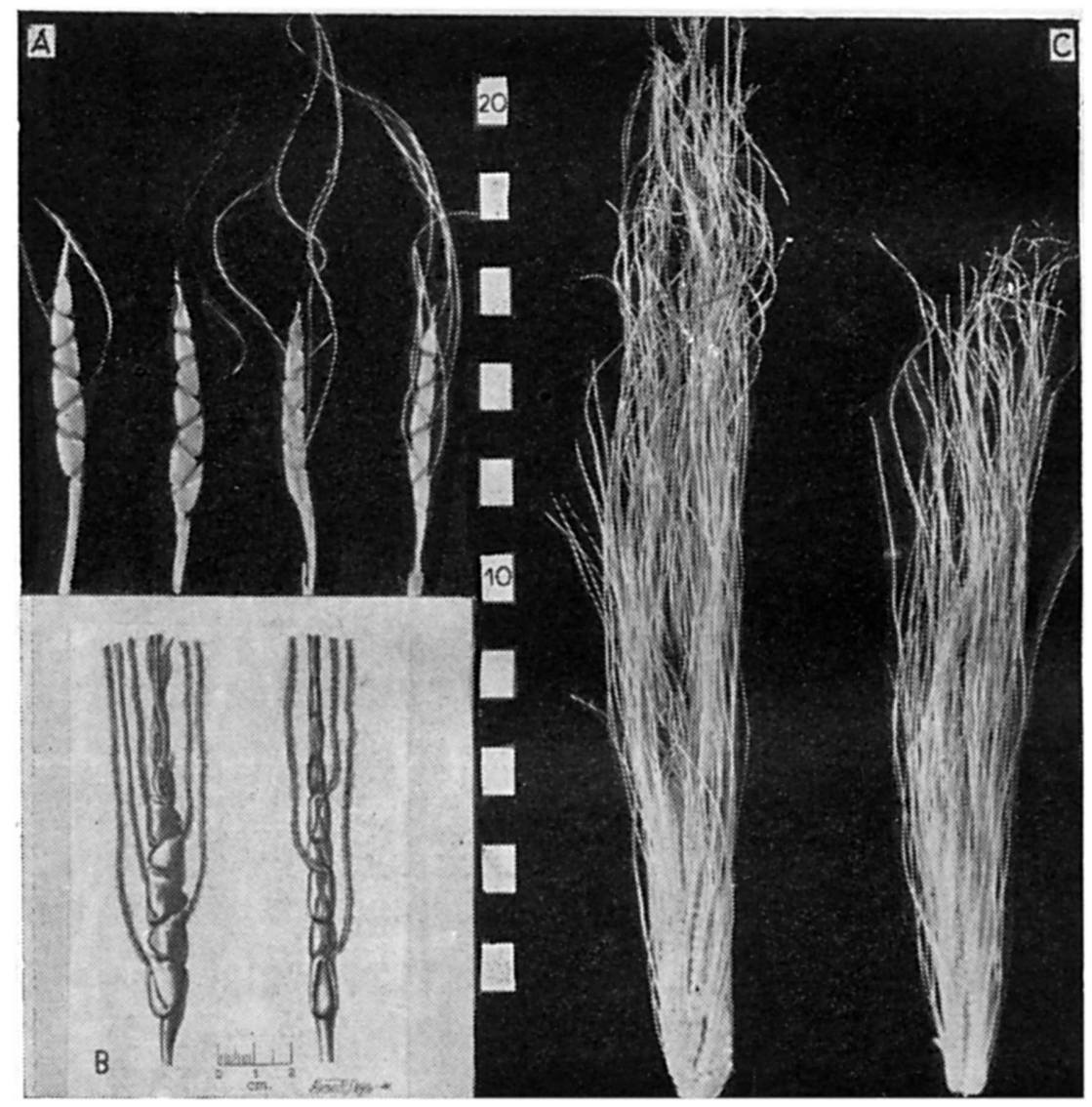

Fig. 4 


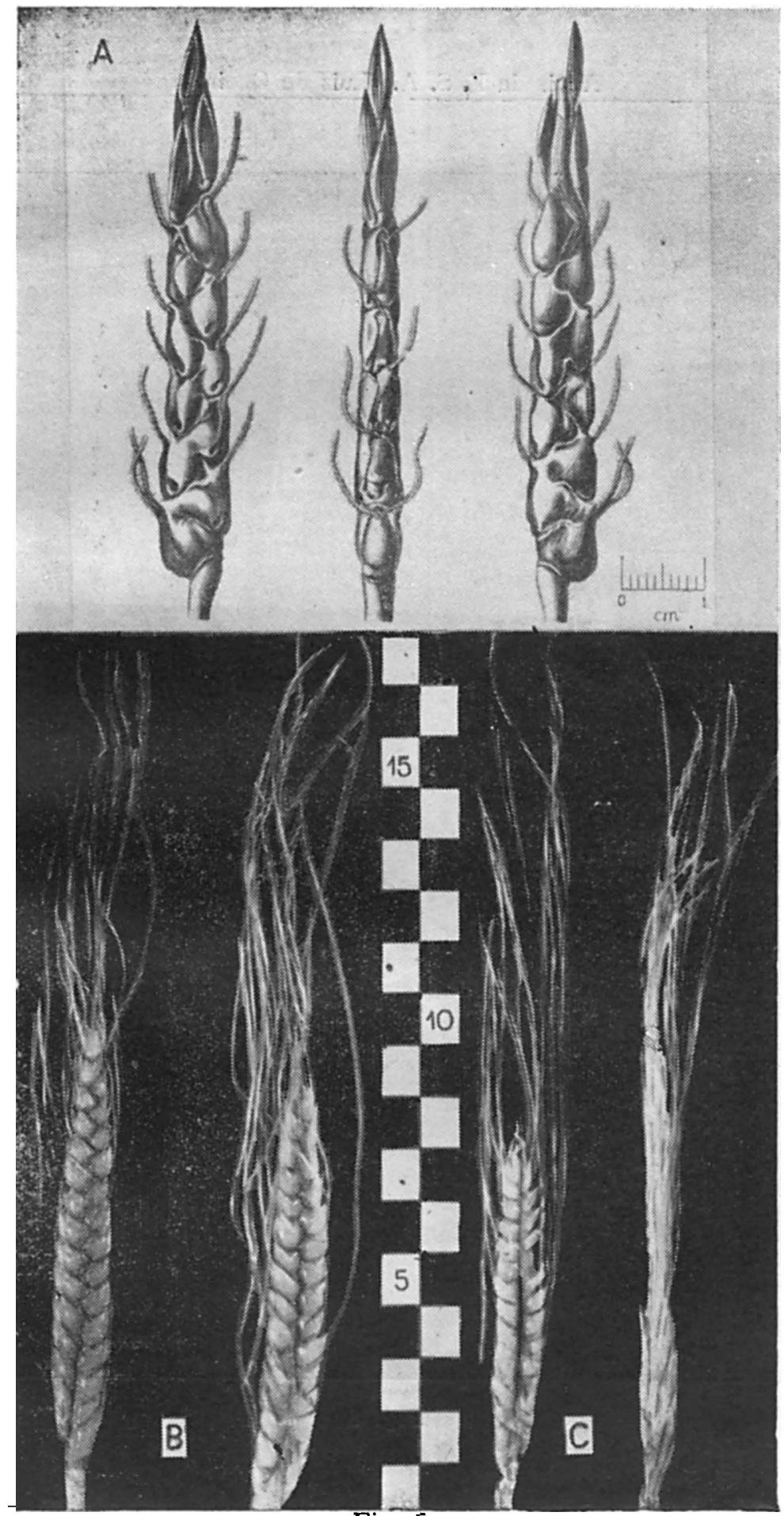

Fig. 5 


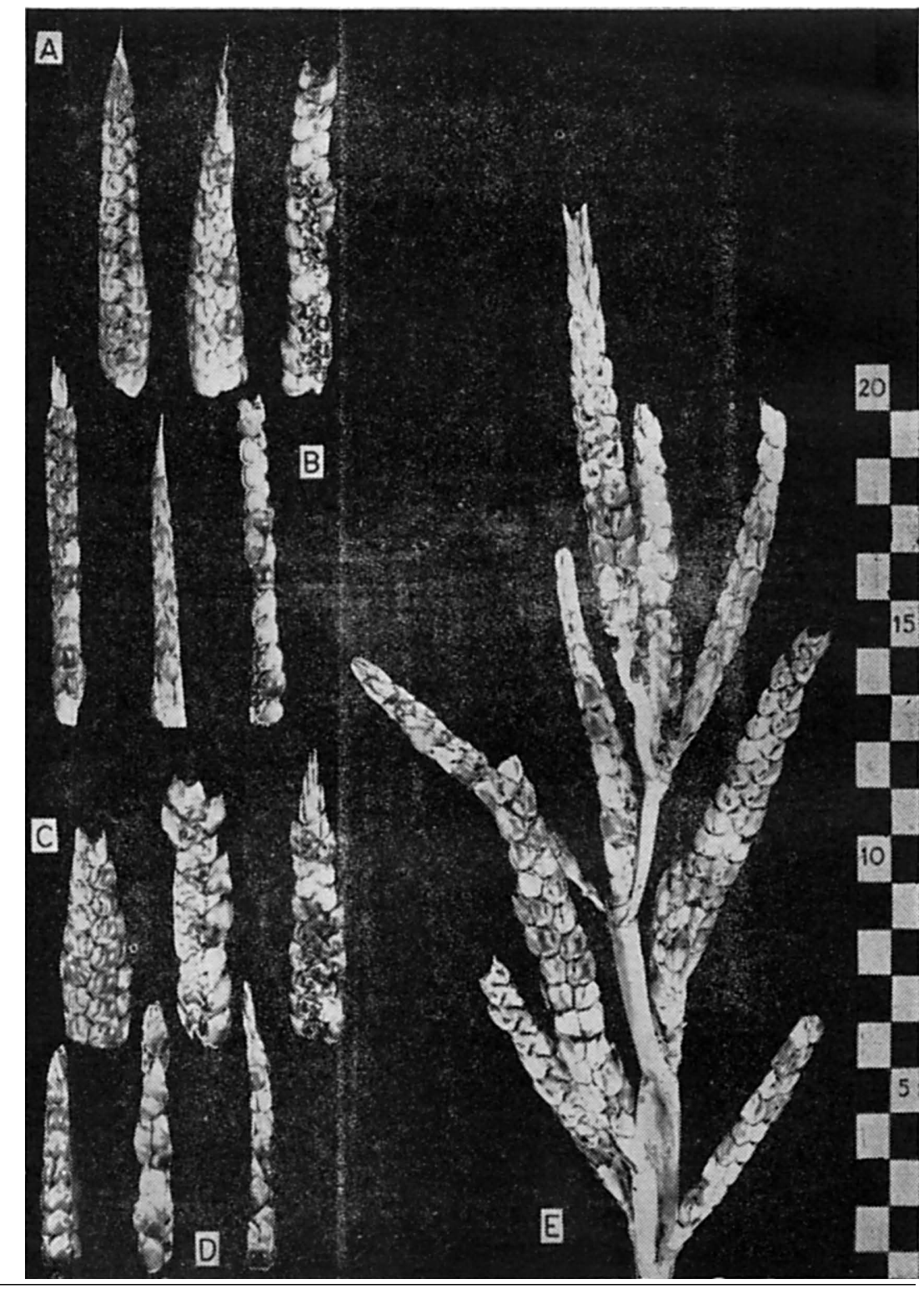

Fig. 6 


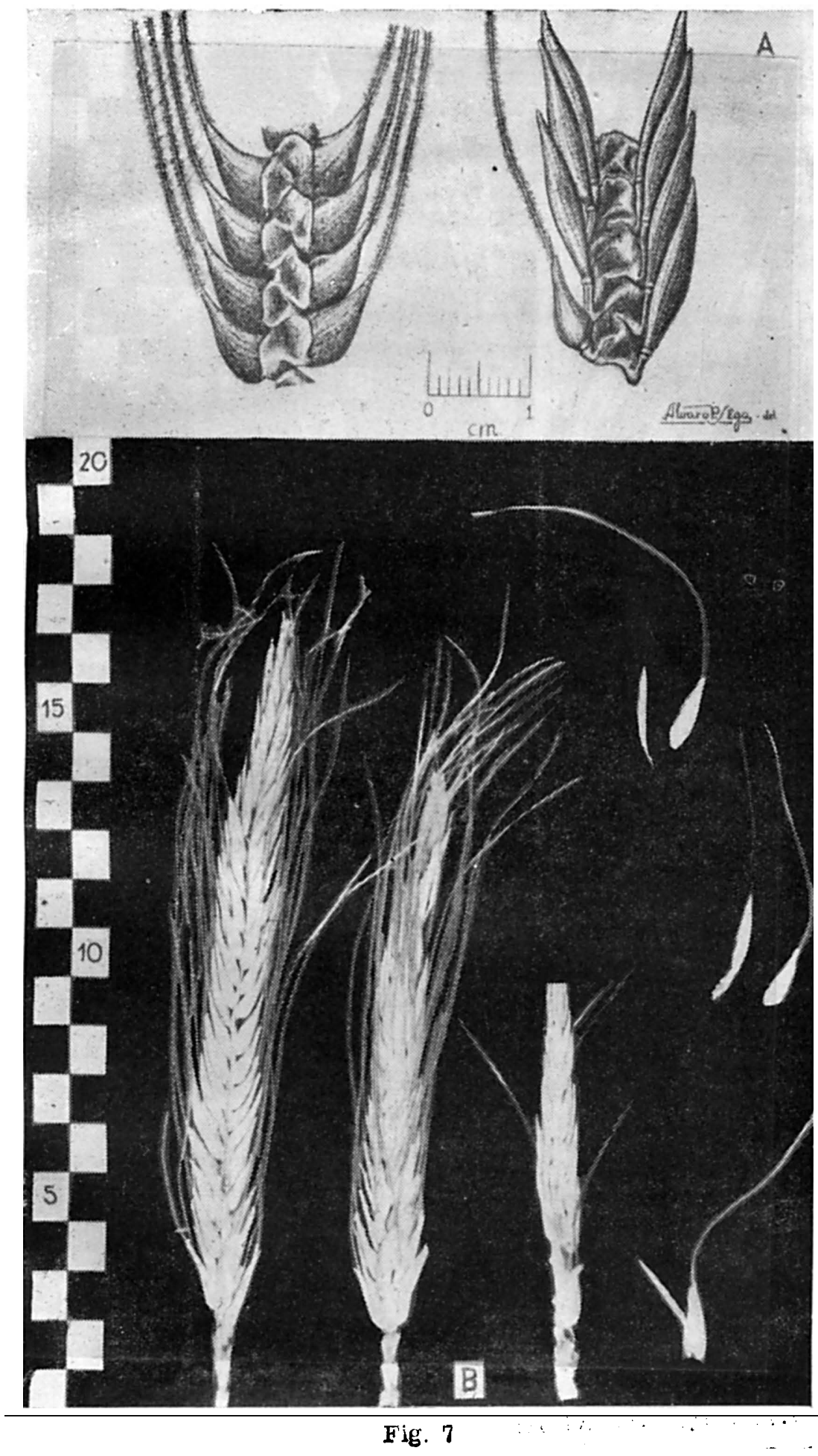




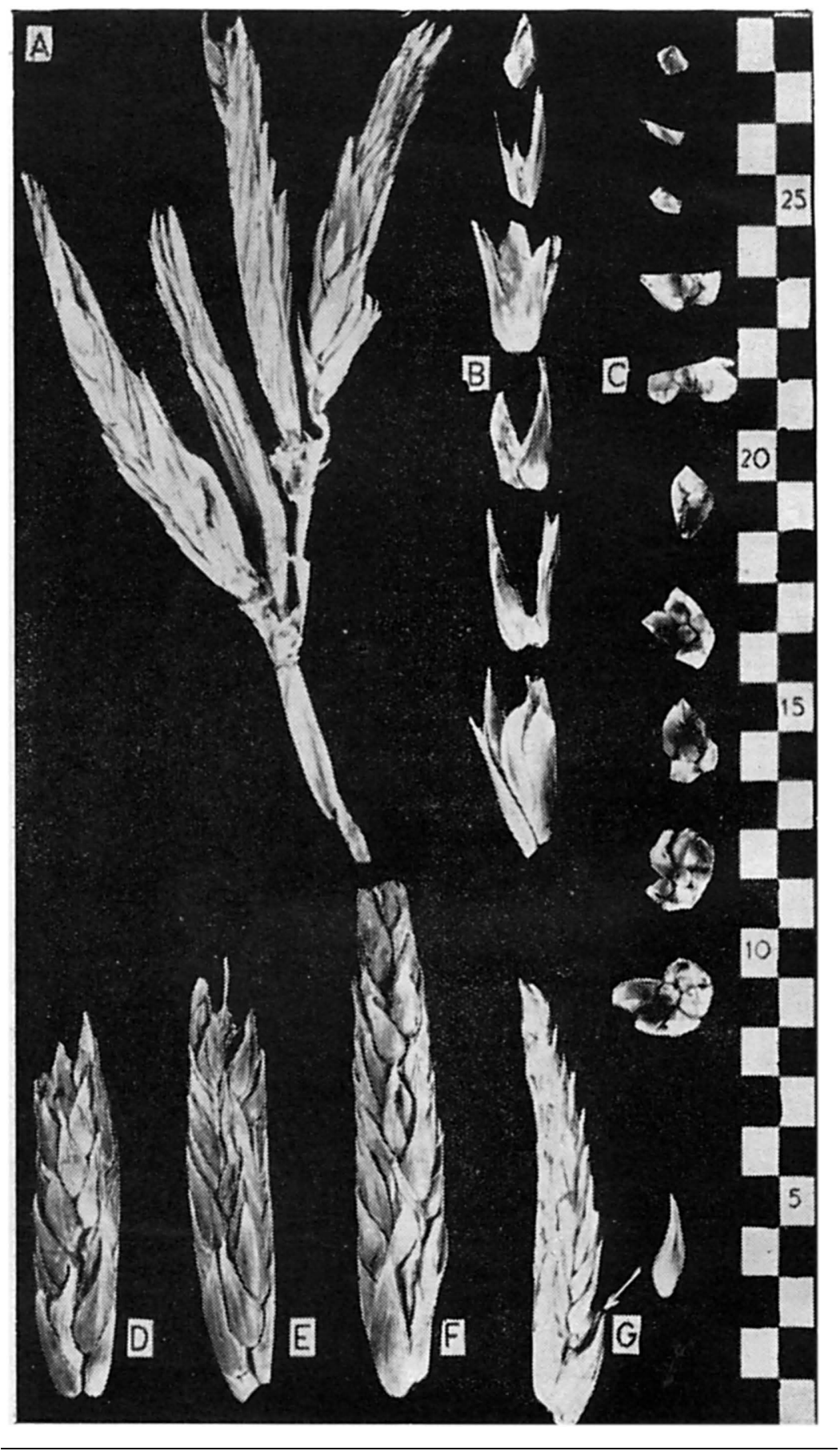

Fig. 8 

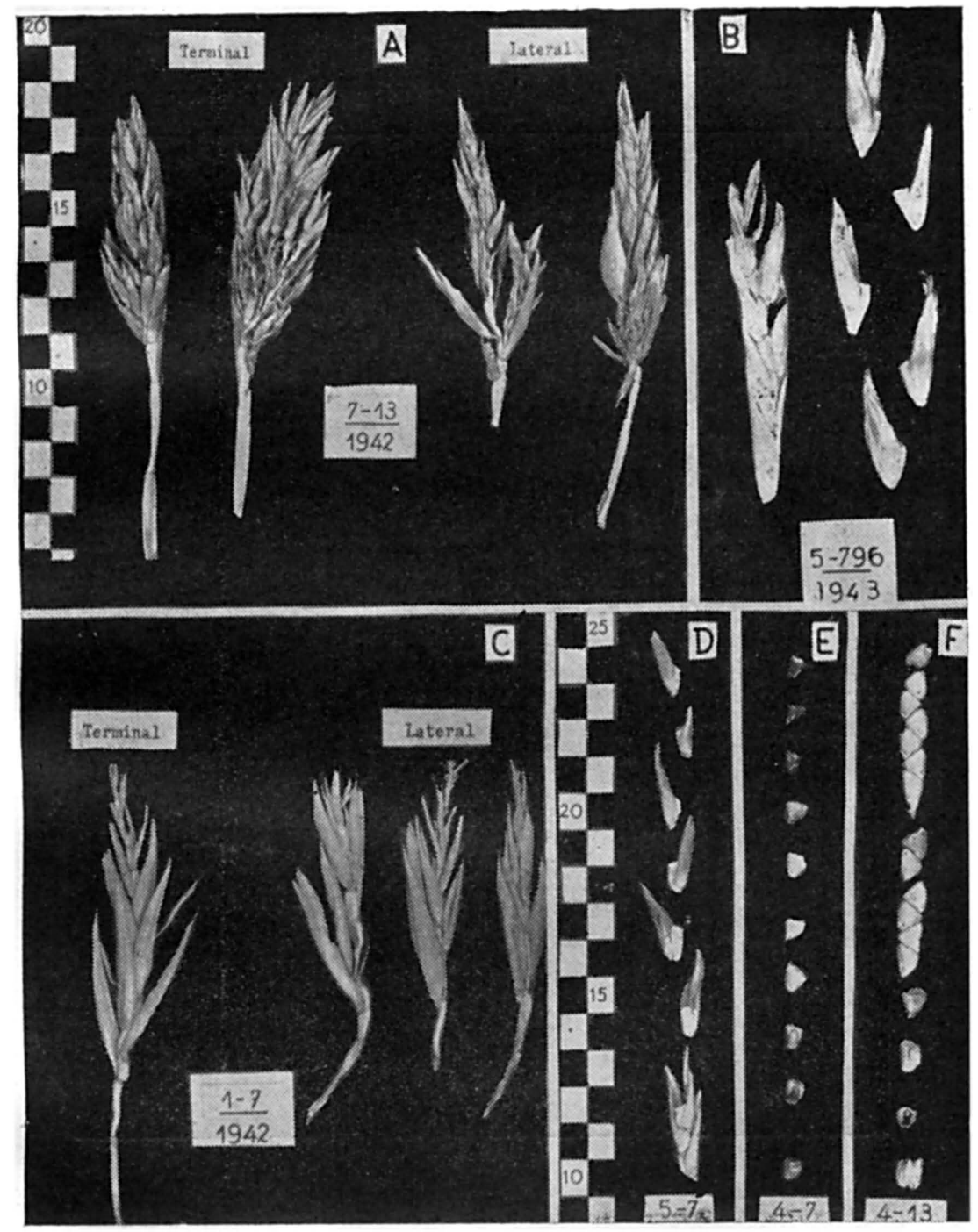

Fig. 9 


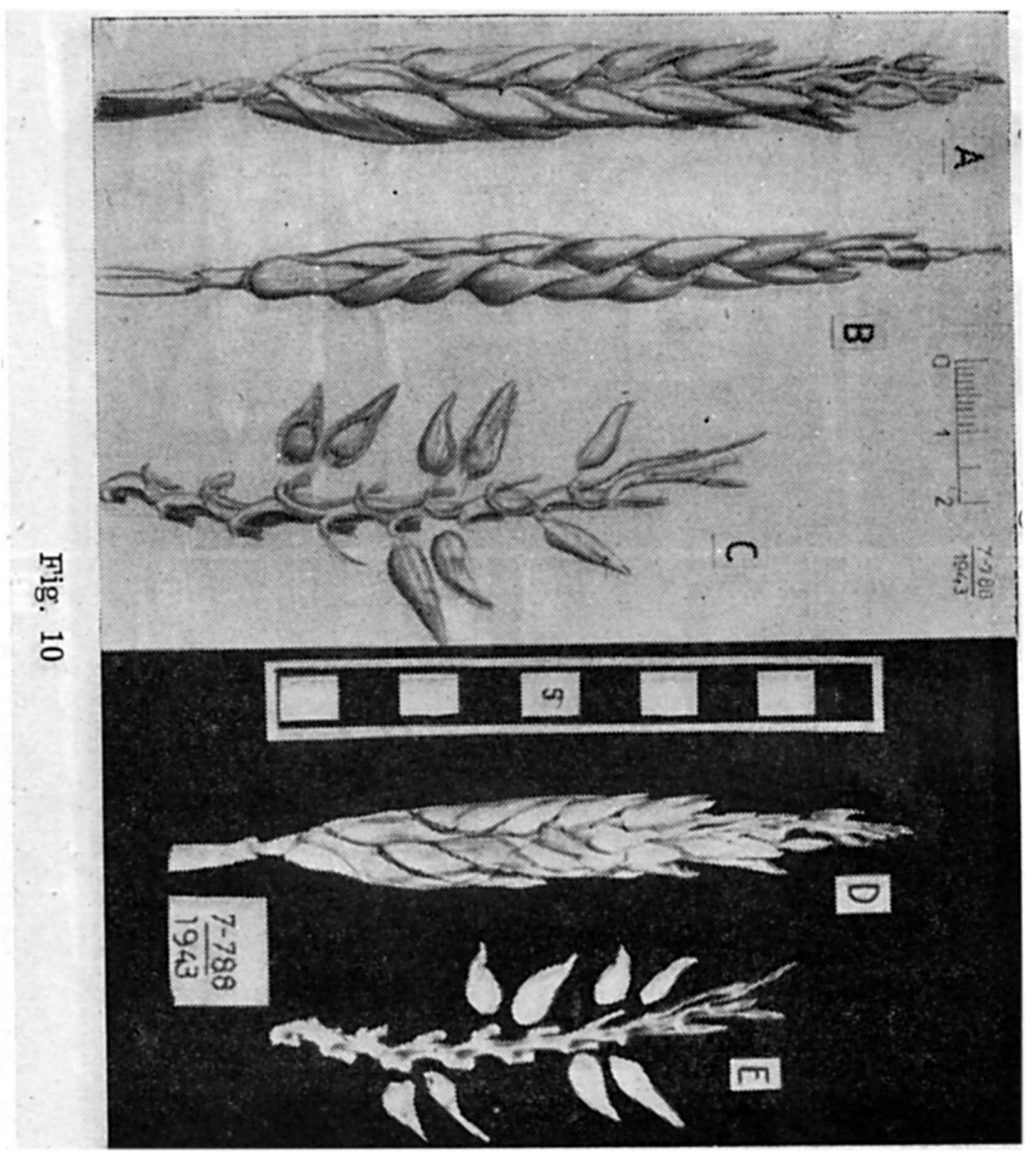




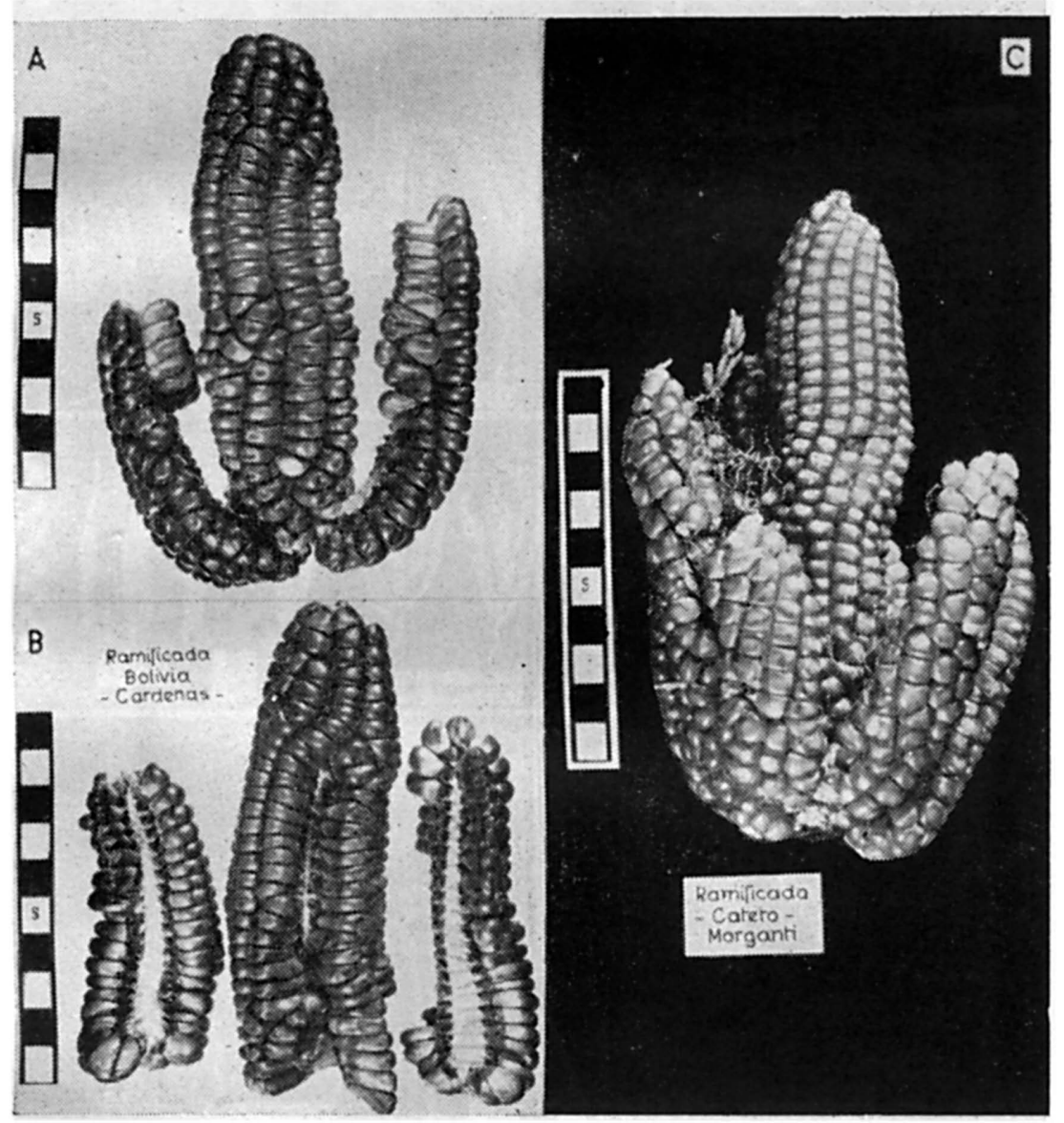

Fig. 11 


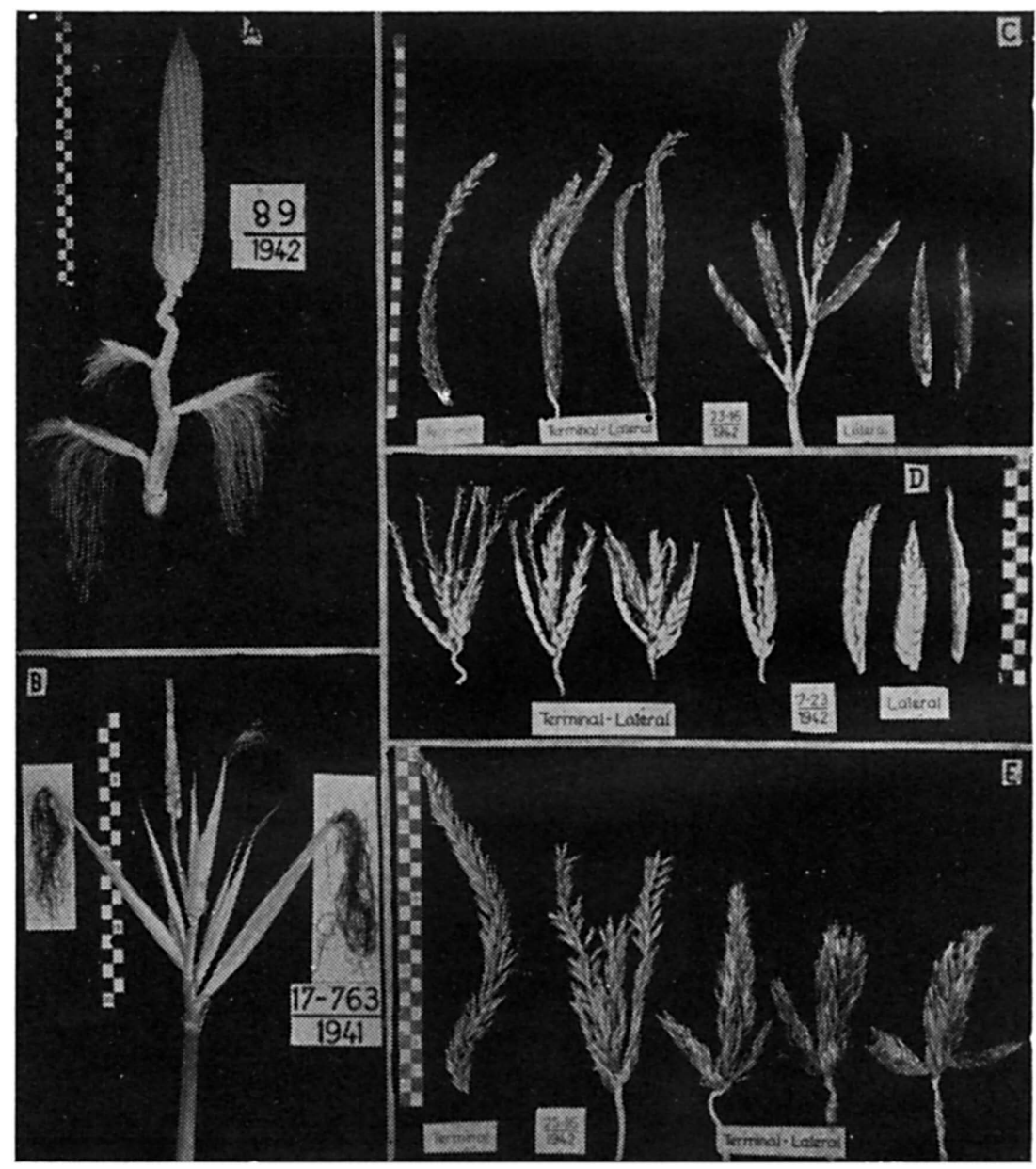

Fig. 12 


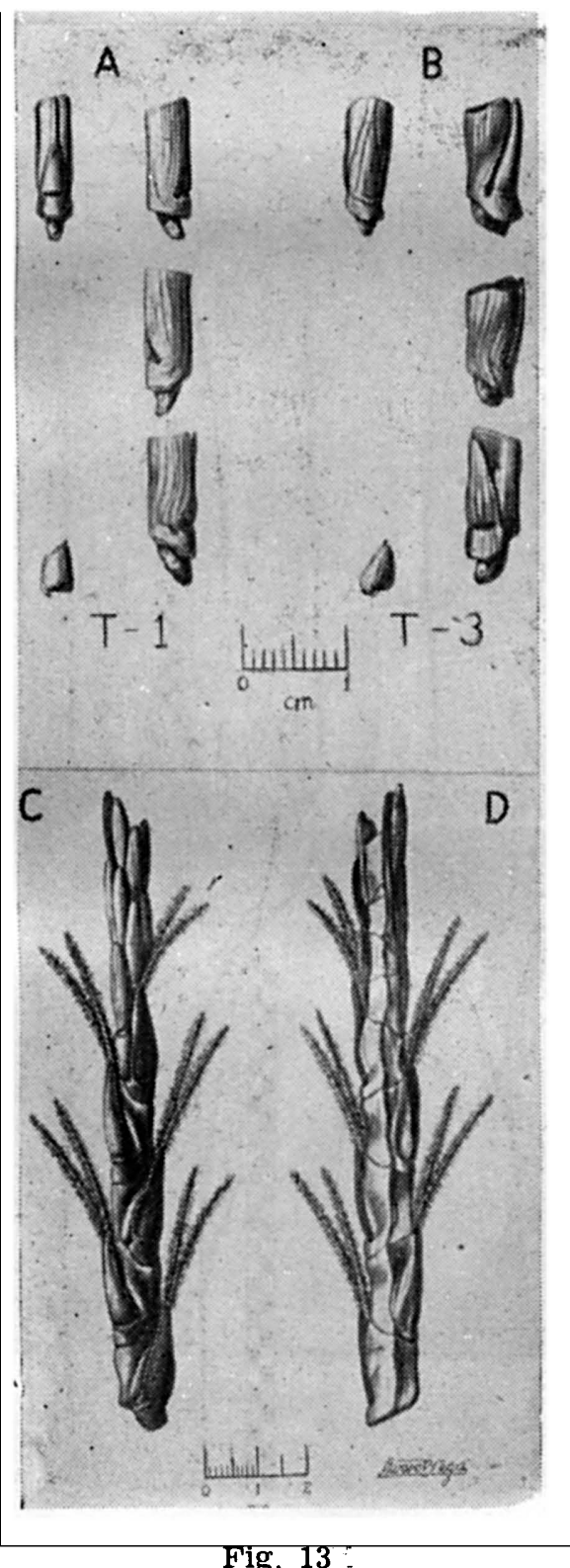




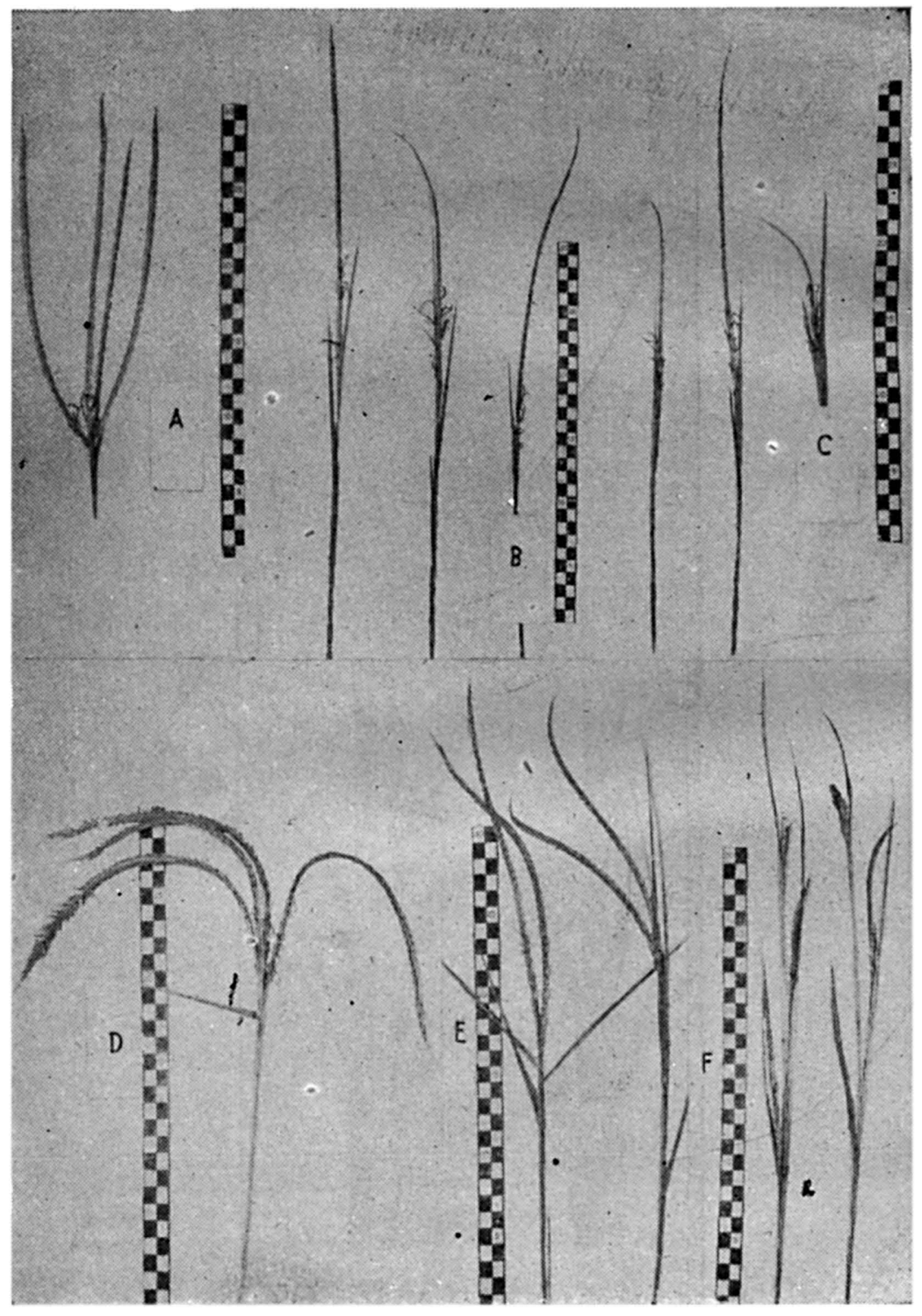

Fig. 14 